\title{
Las denominadas nuevas tendencias en la lucha contra el terrorismo internacional: el caso del Estado Islámico*
}

\author{
New tendencies against international terrorism: \\ the case of the Islamic State
}

\author{
Romualdo BERMEJO GARCÍA \\ Catedrático de Derecho Internacional y Relaciones Internacionales. \\ Universidad de León \\ rberg@unileon.es
}

Resumen: La práctica internacional ha generado unas nuevas tendencias en materia de uso de la fuerza en la lucha contra los grupos armados de actores no estatales, tendencias que se han confirmado en la lucha contra el El. Es más, incluso el Consejo de Seguridad parece abrirse a una cierta descentralización del uso de la fuerza en este ámbito, al adoptar una actitud complaciente con la práctica de los Estados que recurren a la fuerza contra los actores no estatales. Estas tendencias admiten, pues, el derecho de legítima defensa contra los ataques de grupos no estatales, cuando los Estados en cuyo territorio se encuentran no pueden o no quieren poner fin a esas actividades armadas. Sin embargo, la Corte Internacional de Justicia sigue anclada en su crucero, aunque haya ya recibido algunos misiles en su proa, consiguiendo así que se tambalee.

Palabras clave: Terrorismo internacional, actores no estatales, ataque armado, legítima defensa, Hezbolláh, Estado Islámico, Libano, Irak, Siria.
Résumé: Les nouvelles tendances que nous montre la pratique internationale en matière du recours à la force dans la lutte contre les acteurs non-étatiques, se sont confirmées dans la lutte contre l'état islamique. En outre, le Conseil de sécurité semble qu'il est prêt à permettre une certaine décentralisation en matière du recours à la force dans cette matière, en montrant une actitude de complaisance avec la pratique des Etats qui recourent à l'usage de la force contre les acteurs non-étatiques. Ces tendances admettent, done, le droit à recourir au droit de légitime défense contre les attaques de groupes non-étatiques lorsque les Etats, dont le territoire est utilisé par ces groupes ne peuvent o ne veulent mettre fin à ses activités armées. Ceci dit, il faut remarquer que la Cour internationale de justice continue à être ancrée dans son croisseur, bien que elle a été déjà la cible de quelques missiles dans sa proue, en réussissant donc qu'elle soit un peu ébranlée.

Mots-clés: Terrorisme international, acteus non-étatiques, attaque armée, légitime défense, Hezbollah, Etat islamique, Liban, Irak, Syrie.
Abstract: International practice has created new tendencies related to the use of force against armed non-State actors. These tendencies have been confirmed by the fight against the so-called «slamic State» (ISIL). Even UN Security Council seems to be more receptive to a certain decentralisation of the use of force on this issue, as it adopts a kind of complaisant approach to States' practice of using force against non-State actors. Thus, these trends allow the recourse to self-defence against non-State actors' armed attacks, when territorial States are unwilling or unable to stop these armed activities. However, the International Court of Justice has not weighed its anchor yet, even though it has already been hit by some missiles that staggered it.

Keywords: International terrorism, non-State actors, armed attack, self-defence, Hezbollah, Islamic State, Lebanon, Syria.

Sumario: INTRODUCCIÓN. 1. LAS NUEVAS TENDENCIAS SURGIDAS TRAS LOS ATENTADOS DEL 11-S. 2. LAS NUEVAS TENDENCIAS EN LA LUCHA CONTRA LOS DENOMINADOS GRUPOS ARMADOS NO ESTATALES: EL CASO DEL ESTADO ISLÁMICO. 2.1. El Grupo Hezbolláh y sus similitudes con el El. 2.2. Algunas cuestiones jurídicas en torno el conflicto: ¿Podría ejercer Israel el derecho a la legítima defensa? 3. LAS MEDIDAS ADOPTADAS POR LA COMUNIDAD INTERNACIONAL ANTE LOS RETOS PLANTEADOS POR EL EI: A VUELTAS CON LA LEGÍTIMA DEFENSA, Y CONFIRMACIÓN POR LA PRÁCTICA ESTATAL DE LAS NUEVAS TENDENCIAS. 3.1. La ausencia de la figura de la responsabilidad de proteger tanto en el caso sirio como en la lucha contra el El. 3.2. La lucha contra el El a solicitud de Irak y la coalición internacional. 3.3. La lucha contra el El al amparo de la legítima defensa. 4. LA LUCHA CONTRA EL EI Y EL CONSEJO DE SEGURIDAD DE LAS NACIONES UNIDAS. CONCLUSIÓN

* Este trabajo ha sido realizado en el marco del proyecto de investigación I+D+I DER 201564205-R titulado La lucha de civilizaciones. Estado Islámico: retos y consecuencias para la UN, la Comunidad internacional y su Derecho, cuyo IP es el profesor Cesáreo Gutiérrez Espada, Catedrático de Derecho Internacional de la Universidad de Murcia. 


\section{INTRODUCCIÓN}

$\square$

omo se sabe la historia del terrorismo internacional no es nueva, aunque en los últimos tiempos ha ido adquiriendo unos rasgos especiales, poniendo a ciertos conceptos del Derecho internacional en entredicho ${ }^{1}$. Fue, no obstante, después de la Segunda Guerra Mundial, cuando la sociedad internacional asistió a una especie de círculo vicioso y contra-violencia entre los movimientos de liberación nacional y las potencias coloniales. Durante este período, propiciado, es cierto, por la forma utilizada en el desarrollo de muchos conflictos coloniales, hubo cierta confusión a la hora de considerar qué podía ser «terrorismo» y qué era luchar por la libertad, de forma que muchos actos terroristas, y por tanto personas terroristas, pasaron a ser considerados como actos heroicos para conseguir la libertad, y sus autores como «combatientes de la libertad». Hoy en día, no cabe duda de que esta confusión es en gran parte responsable de que no tengamos a nivel internacional una definición generalmente aceptada de terrorismo, generando así graves lagunas en el ámbito del Derecho internacional a la hora de adoptar determinadas medidas para poder defenderse de esta lacra ${ }^{2}$. Y es que la confusión de los conceptos fue tan grande que muchos optaron por la conveniencia de no definirlo como un medio mejor para su defensa frente a tales actos.

Todo el debate que se llevó a cabo sobre esta materia en las Naciones Unidas durante la década de los setenta estaba impregnado de esa doble visión en materia de terrorismo internacional, impidiendo así avances significativos. A este respecto, basta mencionar como botón de muestra los debates en torno a las Resoluciones 2625 (XXV), 2734 (XXV) y 3034 (XXVII). Precisamente esta última Resolución, que es de 11 de enero de 1973, creó un Comité ad hoc de 35 miembros con el fin de que presentara recomendaciones para la vigésimo octava sesión de la Asamblea General. Sin embargo, dicho Comité estuvo debatiendo sobre el tema desde 1972 a 1979, sin llegar a un acuerdo, sobre

1 A este respecto, cfr. RAMÓN CHORNET, C., Terrorismo y respuesta de fuerza en el marco del Derecho internacional, Prólogo de Juan A. Carrillo Salcedo, Valencia, Tiranch lo Blanc, 1992, pp. 27-161; vid. también JENKINS, B.M., «International Terrorism: A New Challenge for the United Nations», en The United Nacions and the Maintenance of International Peace and Security, UNITAR, Nijhoff, 1987, pp. 407-421.

2 Para más detalles sobre esa situación, cfr. Gilbert, G., «The 'Law' and 'Transnational Terrorism'», Netherlands International Law Review, 1995, pp. 3-32. 
todo por la dura oposición de una buena parte de países del Tercer Mundo que se negaban categóricamente a admitir como actos de terrorismo lo que, para ellos, eran sólo actividades llevadas a cabo por los movimientos de liberación nacional en su lucha por la descolonización, contra el racismo, la ocupación extranjera o el apartheid, discurso que imperaba en esos momentos. Esta ambigüedad de las Naciones Unidas en materia de terrorismo internacional no sólo ha planteado serios problemas a la sociedad internacional, sino que ha impedido en muchos casos afrontar el problema con ciertas dosis de realismo, al partir de la premisa de que el terrorismo era sobre todo un fenómeno social ${ }^{3}$. Es más, este discurso onusiano continuó por estas sendas, casi hasta nuestros días a la hora de tratar, por ejemplo, el conflicto israelo-palestino. Y es que si hay un Estado que ha debido de hacer frente permanentemente a actos terroristas, ese es sin lugar a dudas Israel.

Estas dificultades traerían consigo que los Estados se volcaran a tratar el terrorismo desde una perspectiva particular, al dirigirse hacia la adopción de convenios para tratar aspectos específicos relacionados con el tema. Fue así cómo a partir de los años sesenta hasta los ochenta, se adoptaron unos 19 convenios contra el terrorismo, destacando entre ellos aquellos relacionados con la seguridad aérea ${ }^{4}$. A nivel regional destacan sobre todo el Convenio de Washington de 2 de febrero de 1971, para la prevención y represión de actos

3 Claras son a este respecto las ideas del autor estadounidense Nicholas Rostow, quien a este respecto señala sin tapujos lo siguiente: «The United Nations (UN) has always had an ambivalent relationship with the entire idea of terrorism. Some of its constituent parts (governments and international civil servants) and influential elements in the UN firmament (would-be governments, non-governmental organizations, and individuals) have viewed terrorism as a social phenomenon. In contrast, experts outside the UN view terrorism quite differently. Althougt they have had difficulty drftins a precise definition, experts have long agreed that terrorism is a means-a weapon. Terrorism is not a political movement in and of it self, but a tool used by various mouvements». Cfr. RosTow, N., «Before and After: The Changed UN Response to Terrorism since September 11th», Cornell International Law Fournal, vol. 35, 2002, pp. 475-490, p. 475 .

4 Entre estos conviene resaltar el de Tokio, de 14 de septiembre de 1963, sobre infracciones cometidas a bordo de aeronaves, que entró en vigor el 4 de diciembre de 1969, y del que forman parte 172 Estados: el de La Haya, de 16 de diciembre de 1970, sobre represión del apoderamiento ilícito de aeronaves, que entró en vigor el 14 de octubre de 1971, y del que forman parte 174 Estados; y el de Montreal, de 23 de septiembre de 1971, sobre represión de actos ilícitos contra la seguridad de la aviación, que entró en vigor el 26 de enero de 1973, y del que forman parte 175 Estados, con un Protocolo de 24 de febrero de 1988. También se elaboraron otros convenios en materia de seguridad marítima, sobre determinadas personas protegidas (1973), así como sobre la toma de rehenes (1979), etc. Para más detalles, cfr. Higgins, R. y FloRY, M. (eds.), Terrorism and International law, Routledge, Londres, 1997. 
de terrorismo, concluido en el seno de la Organización de Estados Americanos (OEA), que entró en vigor en 1976, y el Convenio europeo para la represión del terrorismo, de 27 de enero de 1977, más conocido como Convenio de Estrasburgo, adoptado en el seno del Consejo de Europa ${ }^{5}$, y en vigor desde 1978. Ninguno de estos dos Convenios da una definición del terrorismo, centrándose sobre todo en la condena de determinados actos. Dicho esto, hay que resaltar que el Convenio de Washington se acerca bastante en cuanto a la conceptualización del terrorismo al hablar en el artículo cuarto de actos que «producen un efecto de terror o intimidación en los habitantes de un Estado o en parte de su población y provocan un peligro común para la vida, la salud, la integridad física o la libertad de las personas, mediante el empleo de métodos o medios que por su naturaleza pueden causar un daño extendido, una seria perturbación del orden público, una calamidad pública, o que consistan en la toma de posesión por la violencia o en la destrucción de una nave, aeronave, o cualquier otro medio de transporte internacional $\gg^{6}$.

$\mathrm{Ni}$ que decir tiene que todo este enjambre jurídico-internacional puede constituir unas bases sólidas para combatir el terrorismo, pero revela al mismo tiempo la fragmentación de la sociedad internacional a la hora de abordar el problema con rigor y eficacia. Y es que la mayoría de estas convenciones sólo obligan a los Estados partes a entablar una estrecha cooperación para investigar los actos y a acusar a los autores bajo el principio aut dedeve aut judicare, lo que no deja de plantear serios problemas como se vió en el caso «Lockerbie» ${ }^{7}$. A pesar de estas graves deficiencias, la propuesta que hizo la India en 1996 de elaborar una convención en materia antiterrorista con mecanismos mucho más sólidos no fue aceptada.

5 Sobre este Convenio, véase entre nosotros VILARIÑo PINTOS, E., «El Convenio Europeo sobre Represión del Terrorismo», Revista de Instituciones Europeas, 1977, pp. 432 y ss. Vid. también FraYsSE-Druesne, G., «La Convention européenne pour la represión du terrorismo», Revue genérale de droit international public, 1978, pp. 970-1023; y VALLÉE, Ch., «La Convention européenne pour la represión du terrorismo», Annuaire français de droit international, 1976, pp. 756784.

6 Estos dos Convenios iban a servir de ejemplo para que otras organizaciones regionales hicieran lo propio. Tal fue el caso del Convenio sobre la supresión del terrorismo de Katmandú, de 4 de noviembre de 1987, adoptado en el marco de la Asociación del Sur de Asia para la Cooperación Regional (SAARC); la Convención árabe sobre la supresión del terrorismo, adoptada en el Cairo el 22 de abril de 1998; la Convención de la Conferencia Islámica para combatir el terrorismo internacional, adoptada en Ouagadougou el 1 de julio de 1999 en el seno de la antigua Organización para la Unidad Africana (OUA), hoy Unión Africana.

7 Sobre este asunto, cfr. infra. 
Desde esta perspectiva, es evidente que se puede hablar de otro fracaso más de las Naciones Unidas, y no es ni el primero ni el último, a no ser que cambie sus estructuras y su forma de actuar. Cada vez más sus órganos parecen conformarse a las leyes de Parkinson, en los que la burocracia roe cada vez más su eficacia ${ }^{8}$. Basta con contemplar los resultados de sus acciones, a pesar de contar con cerca de 70.000 empleados en todo el mundo, para darse cuenta de ello. No basta con decir que el mundo está mejor con la ONU que sin ella, ya que fue creada para cumplir con unos fines determinados, y esa es su función y su responsabilidad. Y tampoco conviene ampararse en que la ONU no funciona por culpa de los Estados, porque cuando el Consejo de Seguridad adopta una Resolución lo hace en tanto que órgano de las Naciones Unidas, lo mismo que cuando no puede adoptarlos.

$\mathrm{El}$ terrorismo, bien sea a nivel interno o en el plano internacional, siempre ha sido visto por el Derecho como un crimen. Lo que ocurre sin embargo, y esto es más común en el plano internacional que en el interno, es que, como ha señalado el Profesor Pierre-Marie Martin, «a menudo, la regla jurídica existe y los Estados están obligados por tanto a cumplirla, pero quizás no se aplique o no pueda aplicarse». Es lo que denomina «el fracaso en la aplicación del Derecho» ${ }^{9}$, y este fracaso se considera en parte que es también el fracaso de las Naciones Unidas. Es obvio que algo de esto ha tenido lugar ante el fenómeno del terrorismo internacional: las reglas existen, pero algunos Estados no las cumplen. Ante esta situación, ¿qué pueden hacer los Estados para defenderse de los actos terroristas? Ya se sabe que la sociedad internacional ha

8 Esta situación está levantando ampollas en algunos países, y sobre todo en los Estados Unidos desde hace algunos años. Significativas son a este respecto, las palabras de Nicholas Rostow, cuando afirma lo siguiente: «The UN organization chart lays out an unwieldy structure of seven principal organs, from which stem as many as 90 offices, agencies, committees, programs, funds, and other entities. Throngs of full-time employees staff each of these sub-organs-translators, statisticians, economists, secretaries, televisión producers, computer experts, lawyers, physicians, carpenters, and others. The UN Secretariat employs 8,700 permanent staf members under its egular Budget, in addition to nearly 5,740 under specially funded programs or projects. Then, like a flying buttress, a contract bureaucracy supports the structure. Sometimes organizations like the Security Council créate institutions to assist its work. The Iraq inspection bureaucracy serves as one example». Rostow, N., «Before and After: The Changed UN Response to Terrorism since September 11th»; op. cit., p. 478. Buenos ejemplos de esta falta de eficacia son el fiasco durante el genocidio de Ruanda o la matanza de Srebrenica, fracasos reconocidos por el propio Secretario General. Pero tampoco se puede decir que su actitud haya sido muy correcta ni muy humanitaria al retirarse de Irak después del atentado en el que murió Sergio Vieira de Melo. Parece como si los atentados terroristas debieran padecerlos otros, pero no el personal de las Naciones Unidas.

9 Cfr. MARTin, P.M., Les échecs du droit international, París, PUF, Que sais-je, 1996, p. 43. 
tenido que hacer frente a este fenómeno, que ha dejado de ser esencialmente interno, para ser utilizado o apoyado por algunos Estados en el ámbito internacional.

Partiendo de estas premisas, hay que reconocer que los actos terroristas constituyen la negación más absoluta de las reglas humanitarias y por lo tanto afectan a la comunidad internacional en su conjunto. Esto es así sólo en la medida en que esos actos terroristas rompan el equilibrio de las relaciones internacionales al implicar agresiones o intervenciones en el territorio de terceros Estados que puedan constituir una amenaza a la paz y a la seguridad internacionales. Desde esta perspectiva, los Estados van a estar obligados a cooperar, tanto positiva como negativamente en la prevención y eventual represión de los actos terroristas ${ }^{10}$.

Desde estas perspectiva, conviene dejar claro que en materia de terrorismo internacional se habla hoy en día de dos etapas bien diferenciadas: la de antes de los atentados del 11-S, caracterizada por un cierto clasicismo a la hora de abordar y sentir el problema, y la de después del 11-S, en la que entran en juego conceptos como la legítima defensa que en algunos casos ya se habían invocado y utilizado en la política internacional, pero que adquieren ahora un mayor relieve al son de la guerra o lucha antiterrorista. Este será pues el hilo conductor de los comentarios siguientes.

\section{LAS NUEVAS TENDENCIAS SURGIDAS TRAS LOS ATENTADOS DEL 11-S}

Los ya muy comentados atentados del 11-S cambiarían las premisas y las perspectivas a la hora de afrontar el terrorismo internacional. La magnitud de la tragedia en cifras absolutas, el país atacado, la facilidad con la que todo parece haberse desarrollado hizo que la conmoción mundial fuera enorme, recibiendo las autoridades y el pueblo estadounidense la solidaridad y el apoyo de la mayoría de los países, incluyendo, por supuesto, el de Rusia, pero también los de China o la India. Es cierto que algunos países apoyaron a los Estados Unidos más con la cabeza que con el corazón ${ }^{11}$, aunque lo cierto es que el

10 Cfr. CARRILlo SAlCedo, J.A. y Frowein, E., Les aspects juridiques du terrorismo international. Académie de Droit International de La Haye. Centre d'études et de recherches de droit international et des relations inernationales. La Haya, 1988, Nijhoff, p. 25 y ss.

11 Destacan entre ellos algunos países árabes o islámicos, cuyos pueblos además no dudaron en salir a la calle para festejar los acontecimientos. Tampoco faltaron declaraciones de algunos líderes 
mundo descubrió conmocionado cómo unos terroristas golpearon duramente a la primera potencia mundial. Por eso, precisamente, muchos Estados esperaron con recelo y preocupación la reacción de los Estados Unidos a los $\operatorname{atentados}^{12}$, aunque estos dieron tiempo al tiempo, evitando así precipitarse y dar palos de ciego.

Y es que los Estados Unidos son conscientes de que muchos Estados han pecado de exceso de benevolencia, de ingenuidad, o quizás de mala fe, cuando en varias ocasiones han considerado a ciertos grupos terroristas como «héroes», «mártires» o «luchadores de la libertad». Pero esto no sólo ha ocurrido en el seno de algunos Estados, sino también, y quizás esto sea lo más grave, en parte de la sociedad occidental. Por eso había que poner el reloj en hora..., lo que explica que la primera batalla la dieran los Estados Unidos en el seno del Consejo de Seguridad, con el fin de mostrar al mundo que quería contar con el apoyo de la comunidad internacional en su lucha contra el terrorismo.

La intención de los Estados Unidos al llevar a los atentados ante el Consejo de Seguridad era que se pronunciara sobre la cuestión, y así lo hizo al adoptar un día más tarde la ya famosa Resolución 1368, en cuyo texto se nota su adopción de forma apresurada. Durante los debates, varios representantes y el propio Secretario General dejaron claro la necesidad de juzgar a los autores de los ataques, a sus organizadores, así como a aquellos que los han apoyado, financiado o dado cobijo ${ }^{13}$. En realidad, todo esto no es nada original, pues ya se encontraba en otras resoluciones anteriores. Sin embargo, en estas declaraciones se oyen también frases más contundentes que no eran muy comunes en esos foros, como que los ataques eran un crimen contra la humanidad, contra la paz, la democracia y los valores sobre los que se apoyan las Naciones Unidas.

de organizaciones terroristas, como la del jeque Abdalá Shami, jefe político de la Yihad Islámica, señalando que «son los Estados Unidos los que lideran el terrorismo internacional por su apoyo ciego a Israel», o que el Mossad israelí participó en los atentados del 11-S. Cfr. $A B C$, de 19 de septiembre de 2001, p. 32.

12 Esto no podía ser menos visto el poder de la hiperpotencia. Como ha señalado Ignario Ramonet, «... Si la supremacía de los Estados Unidos era grande, desde ahora es aplastante. Las demás potencias occidentales (Francia, Alemania, Japón, Italia e incluso el Reino Unido, parecen liliputienses a su lado. La prueba más aplastante del impresionante poder de intimidación que ejerce Estados Unidos, ha sido lo ocurrido al día siguiente del 11 de septiembre... En cuanto a Rusia, no dudó un segundo. Vladimir Putin fue el primero en contactar con Bush... para expresarle su solidaridad... ya no hay a escala planetaria ninguna coalición susceptible de contrapesar a Estados Unidos. La dominación militar de éste, es ahora absoluta». Cfr. «El nuevo rostro del mundo», Le Monde diplomatique, edición española, diciembre 2001, p. 3.

13 Cfr. Doc. SC/7143, de 12 de septiembre de 2001. 
Si nos centramos en el tenor literal de la Resolución, este es muy breve, aunque ha sido objeto de alguna polémica. En el preámbulo de la Resolución se señala que hay que «combatir por todos los medios las amenazas a la paz y a la seguridad internacionales», aunque lo más importante es que reconoce «el derecho inmanente de legítima defensa individual y colectiva de conformidad con la Carta de las Naciones Unidas ${ }^{14}$. Por lo demás, después de condenar «en los términos más enérgicos los ataques terroristas» señala que los Estados deben colaborar para llevar ante la justicia a los autores, organizadores, patrocinadores, etc. La Resolución termina expresando que el Consejo está dispuesto a tomar «todas las medidas necesarias» para responder a los ataques ${ }^{15}$.

Inútil de señalar que esta Resolución, y la Guerra que seguiría en Afganistán, han sido objeto de numerosos estudios y comentarios ${ }^{16}$. En realidad, la cuestión más espinosa al respecto era saber si efectivamente se podía considerar que hay frente a ataques de esa índole el derecho de legítima defensa o no. El hecho de que el Consejo de Seguridad lo haya reconocido no es óbice para poder plantearse la cuestión, ya que no es ningún órgano legislativo mundial ${ }^{17}$. Así

14 Sobre esta cuestión cfr. infra.

15 Conviene resaltar que esta expresión figura en el texto inglés como «all necessary steps» y no «all necessary means» que era la expresión que figuró por primera vez en la Resolución 678 del 29 de noviembre de 1990 en torno al conflicto Irak-Kuwait.

16 En España, los atentados del 11-S fueron objeto de varios estudios en el Anuario de Derecho Internacional, 2001, pp. 5-56, y en la Revista Española de Derecho Internacional, 2001, pp. 125302. También hay que mencionar que algunos de los estudios que figuran en la Colección Escuela Diplomática, $\mathrm{n}^{\circ}$ 7, sobre Los nuevos escenarios internacionales y europeos del Derecho y la Seguridad, Madrid, 2003, bajo la dirección del Profesor Alejandro del Valle Gálvez, tienen como trasfondo los atentados del 11-S, como los de Juan Antonio Carrillo, Gabriel Sistiaga, Gustavo de Arístegui y San Román y Romualdo Bermejo García. Algo similar ha ocurrido en otros países, destacando los estudios que dedica el American Fournal of International Law, 2001, pp. 833-872, que constituyen un fiel reflejo de la doctrina estadounidense. Puede vderse también el estudio de Condorelli, H., «Les attentats du 11 septembre et leurs suites: Où va le droit international?», Revue genérale de droit international public, 2001, pp. 829-848, así como los comentarios de López-Jacoiste Díaz, E., Actualidad del Consejo de Seguridad de las Naciones Unidas. La legalidad de sus decisiones y el problema de su control, Thomson-Civitas, Madrid, 2003, pp. 367-379.

Una obra colectiva interesante para ver el pensamiento de la doctrina europea en esos momentos, es la de Bannelier, K. et al. (eds.), Le droit international face au terrorismo, Paris, Pedone, 2002, 356 p. En los Estados Unidos, FALK, R., The Great Terror War, New York, Olive Branch Press, 2003; una recensión de esta obra, por cierto muy completa, ha sido realizada por GUTIÉRREZ, G.S., «The Ambiguity of 'Megaterrorism'», Cornell Internatgional Law Journal, 2003, pp. 367-379. En esta obra el autor americano se muestra crítico con la forma de llevar a cabo la guerra contra el terrorismo.

17 Cfr. Koskenniemi, M., «The Police in the Temple-Order, Justice and the UN: a Dialectical View», European Fournal of Public International Law, 1995, p. 325. 
las cosas, sobre esta cuestión surgieron opiniones para todos los gustos, tanto en Europa como en los Estados Unidos y en otras partes del mundo, aunque resumiendo se puede decir que esas opiniones iban en las tres direcciones siguientes: a) los que reconocen el derecho de legítima defensa; b) los que lo niegan sin más ${ }^{18}$; y c) los que lo niegan, aunque se sienten insatisfechos con esta situación. El autor de este trabajo ha defendido antes del 11-S la primera tesis, y lo volvimos a hacer también tras los atentados, reconociendo que dichos ataques dan lugar a la aplicación del derecho de legítima defensa ${ }^{19}$.

Sin embargo, la Resolución 1368 no dice que los ataques sean «armados», término recogido en la Carta. ¿Estamos pues ante un nuevo ejemplo de ataque que sin ser estrictamente «armado» de lugar al derecho de legítima defensa?. En nuestra opinión sí, sobre todo cuando se piensa en la capacidad de destrucción de los medios utilizados y la intención de los que los llevaron a cabo, así como de los que los ordenaron. El representante ruso ante el Consejo de Seguridad no se sonrojó al calificar tales ataques como «an unprecedented act of agresión», dejando clara la posición de la Federación Rusa ${ }^{20}$. De esta misma opinión son también autores como Weckel $^{21}$, Wedgwood ${ }^{22}$ y Eisemann ${ }^{23}$, entre otros, sobre todo estadounidenses ${ }^{24}$. Entre nosotros, el Profesor Gutiérrez Espada dejo también abierta esa posibilidad, después de señalar que hasta esas fechas en general no se habían considerado así. No obstante, el citado Profe-

18 Esta tesis casa vez se defiende con menos brío, e incluso se puede decir que se está desinflando.

19 A este respecto, cfr. López-Jacoiste Díaz, E., Actualidad del Consejo de Seguridad de las Naciones Unidas, op. cit., pp. 86-87. En cuanto al Profesor Bermejo ya defendió este derecho antes de los ataques del 11-S. A este respecto, cfr. El marco jurídico internacional en materia de uso de la fuerza, op. cit., nota 23 , pp. 381 y ss.; $\mathrm{y}$ «Cuestiones actuales referentes al uso de la fuerza en el Derecho internacional», Anuario de Derecho Internacional, 1999, p. 21, en donde se señala que «... una cosa está clara: la comunidad internacional ni puede ni debe dejar sin respuesta los actos terroristas». Y después de los ataques del 11-S, cfr. «El Derecho internacional frente al terrorismo: ¿nuevas perspectivas tras los atentados del 11 de septiembre?», Anuario de Derecho Internacional, 2001, pp. 5-25, especialmente 19-22.

20 Cfr. Doc. SC/7143, declaración del representante ruso Sergei Lavrov.

21 Cfr. WeCKEL, P., «Le statut incertain des détenus su la base américaine de Guantánamo», revue générale de droit international public, 2002, p. 366.

22 Cfr. Wedgwood, R., «Al Qaeda, Terrorism and Military Commissions», American fournal of International Law, 2002, p. 328.

23 Cfr. Eisemann, P.M., «Attaques du 11 septembre et exercice d'un droit natural de légitime défense», in BANNELIER, K. et al. (ed.), Le droit international face au terrorisme, op. cit., nota 42, pp. 239-248. Breve y conciso, en este artículo el autor defiende el derecho natural de legítima defensa de los Estados Unidos de una forma clara.

24 Cfr. Los autores en American Fournal of International Law, 2001, op. cit., nota 42 y Cornell International Law Fournal, 2002 y 2003. 
sor piensa que a causa de la magnitud de los ataques y las destrucciones efectuadas es posible que en el futuro sean considerados como ataques armados ${ }^{25}$.

Los que niegan el derecho de legítima defensa se escudan, sin embargo, en que los ataques no han sido cometidos por un Estado ni se ha demostrado que un Estado haya tenido una participación sustancial, siguiendo así las directrices de la Corte Internacional de Justicia en el asunto de Nicaragua que se apoyaba en el artículo 3.g de la Resolución 3314 (XXIX) sobre la agresión de $1974^{26}$. Frente a estos argumentos hay que decir lo siguiente. Es cierto que al principio no se sabía con mucho detalle el grado de participación del Gobierno talibán de Afganistán en los ataques, aunque poco a poco se fueron conociendo datos que demostraban que su participación no sólo había sido sustancial, sino que en realidad lo que ocurría era que en Kabul mandaban tanto los de Al-Qaida como los talibanes. Y es que, se sabe y está probado, que el Gobierno talibán prestó su territorio para dar refugio a esa organización, permitiendo además que estableciera bases propias para su propio entrenamiento y cuando se le solicitó la entrega de Osama Bin Laden, se negó a ello.

Quedaban, por último, los que no se atrevían a reconocer el derecho de legítima defensa, pero que se encontraban desconcertados por la situación y utilizaban términos como que el Estado atacado tenía el derecho a protegerse, así como proteger a sus ciudadanos, aunque sin recurrir a la figura de la legítima defensa. Como se puede comprender esta tesis reviste una cierta ingenuidad, como veremos más tarde, pues implica en realidad dejar al Estado víctima en la mayoría de las ocasiones sin protección. Tanto es así que si nos fijamos en Israel, y hubiera seguido esta tesis, hoy en día quizás ya no existiría.

Hechas estas consideraciones, conviene remarcar también, que en relación con los ataques del 11-S, la OTAN activó el artículo V del Tratado fun-

25 Las cautelas que adopta son importantes, aunque deja esa posibilidad abierta cuando dice que esos actos «... llevan a pensar que... podrían considerarse equiparables en sus objetivos y efectos a muchos ataques armados ortodoxamente desarrollados, por lo que serían un precedente que de repetirse debería tenerse en cuenta pro futuro a estos efectos». Cfr. GUTIÉRREZ ESPADA, C., « ¿No cesaréis de citarnos leyes viendo que ceñimos espada? (a propósito del 11-S)», Anuario de Derecho internacional, 2001, pp. 31-32.

26 Esta es la tesis que defendió justo tras los atentados el Profesor de Ginebra Marcelo Kohen (cfr. KoHEN, M.G., «L'arme de civilisation, c'est le droit», Le Temps (Ginebra) de 17 de septiembre de 2001, p. 7). Para este autor, no sólo no cabe invocar la legítima defensa, sino que tampoco estaría admitido llevar a cabo ninguna clase de represalia, cuando señala: «... uné éventuelle action armée sur le territoire d'un Etat, du fait qu'il abrite des terroristes, sans le consentement de l'Etat en cause ou sans l'autorisation du Conscil de Sécurité, pourrait tout au plus constituir des représailles armées, lesquelles sont également interdites en droit international». 
dacional, considerándolos así como ataques $\operatorname{armados}^{27}$. Nada nuevo bajo el sol hay en realidad en esta decisión de la OTAN, ya que era algo programado en el párrafo 24 del nuevo «Concepto Estratégico de la Alianza», aprobado por los Jefes de Estado y de Gobierno en la reunión del Consejo del Atlántico Norte que tuvo lugar en Waqshington los días 23-24 de abril de 1999, en donde después de recordar que cualquier ataque armado contra el territorio de los aliados estaría cubierto por los artículos 5-6 del Tratado de Washington, reconoce que la seguridad de la Alianza debe analizarse en un contexto global, ya que puede ponerse en peligro por otros riesgos que tienen un carácter más general, particularmente los actos terroristas, etc. etc. Como se puede ver, no iba la OTAN tan descarriada como se puede comprobar ahora, y también entonces. No obstante, ya se sabe que este nuevo «Concepto Estratégico» sufrió críticas acerbas no siempre muy justificadas, por no decir que en algunos casos parecían tendenciosas. Hoy en día todo parece indicar que los Jefes de Estado y de Gobierno de la Alianza tenían la mente más clara de lo que algunos pretendían ${ }^{28}$.

Pero el Consejo de Seguridad no se detendría en la Resolución 1368, sino que inició una lucha de mayor calado adoptando el 28 de septiembre, también por unanimidad, la Resolución 1373. Esta Resolución, mucho más elaborada que la 1368, fue adoptada sólo un día después de que el representante estadounidense por aquel entonces, John Negroponte, presentara la propuesta, lo que revelaba sin lugar a dudas el gran consenso existente en el seno del Consejo. Esta Resolución, que fue considerada como un hito histórico por el Presidente del Consejo, el francés Jean-David Levitte ${ }^{29}$, reconoce también el derecho de legítima defensa, pero plantea muchas cuestiones que no se pueden desarrollar en un trabajo de esta índole. Solo queremos apunar por tanto que en ella se prevén una serie de medidas para la prevención y represión de la financiación del terrorismo, insistiendo en que los Estados se abstengan de proporcionar cualquier tipo de apoyo, activo o pasivo, a los terroristas y asegu-

27 Para más detalles, cfr. Miller, J., «Comments on the Use of Force in Afganistán», Cornell International Law fournal, 2002, pp. 605-610.

28 Sobre este nuevo «Concepto Estratégico», cfr. RAMÓn CHORnet, C., «La OTAN, Vicaria de la ONU: reflexiones sobre el sistema de seguridad colectiva, a la luz del Nuevo Concepto Estratégico acordado en Washington», Anuario de Derecho Internacional, 1999, pp. 363-383.

29 A este respecto, el Presidente del Consejo por aquel entonces declaró con cierta euforia que «algunas veces en la vida diplomática se tiene la sensación de que se está haciendo historia. Creo que el Consejo ha hecho historia al adoptarse una ambiciosa y completa estrategia para luchar contra el terrorismo en todas sus formas y en todo el mundo». 
ren su enjuiciamiento, como no podía ser de otra manera. Conviene destacar, sin embargo, que la Resolución no define tampoco el terrorismo, cuestión que fue excluida deliberadamente, aunque sí prevé el establecimiento de un comité antiterrorista para coordinar la recta aplicación de las medidas, Comité que está en funcionamiento ${ }^{30}$.

Que la lucha contra el terrorismo debe llevarse a cabo respetando los derechos humanos y el Derecho internacional humanitario es obvio, y, en nuestra opinión, sí que hubiera sido conveniente que algún párrafo de esta Resolución hiciera expresamente alusión a ello ${ }^{31}$. En el preámbulo sí que se reafirma «la necesidad de luchar con todos los medios, de conformidad con la Carta de las Naciones Unidas», sin más, y ahí se tendría que haber continuado haciendo referencia al respecto de los derechos humanos.

Pero aún tenemos otro argumento de peso que venía a confirmar una casi aceptación general de que en estos caso el Estado atacado tiene el derecho de legítima defensa, ya que tanto las Naciones Unidas como la mayoría de los Estados, salvo contadas excepciones como Irak, Irán, Corea del Norte, Cuba y Malasia, no se opusieron en ningún aspecto a las operaciones bélicas contra Afganistán. Es más, como ya señaló el Profesor Condorelli, raros fueron los altos responsables políticos que salieron al paso defendiendo la idea de que no había legítima defensa ${ }^{32}$.

Todas estas consideraciones nos llevan a hacer la reflexión siguiente. Es evidente que tras los atentados del 11-S algo ha cambiado en el Derecho internacional tras las resoluciones adoptadas por el Consejo de Seguridad y la aceptación activa o pasiva de la comunidad internacional. En el año 2001, nos preguntábamos si era posible reconocer que «ante una práctica internacional capaz de generar una norma in statu nascendi, según la cual para poder invocar la legítima defensa no sería necesario un ataque armado...», en sentido clásico,

30 Cfr. Rosand, E., «Security Council Resolution 1373, the Counter-Terrorism Commitee, and the Fight Aguinst Terrorism», American fournal of International Law, 2003, pp. 333 y ss.

31 A este respecto, ver el interesante trabajo de OLIVIER C., «Human Rights Law and the International Fight Against Terrorism: How do Security council resolutions Impacto on States» Obligations under International Human Rights Law? (Revisiting Security Council Resolution 1373)», Nordic Fournal of International Law, 2004, pp. 399-419. Ver también NEUMAN, G.L., «Comment, Counter-Terrorist Operations and the Rule of Law», European Fournal of Public International Law, 2004, pp. 1019-1029, quien no comprende la desconfianza existente en torno a los tribunales militares.

32 Cfr. Condorelli, L., «Les attentats du 11 septembre et leurs suites: où va le droit international?», op. cit., p. 840. 
es decir de un Estado contra otro Estado. Es más, también nos preguntábamos si «se podría ya hablar de una costumbre instantánea a la luz del consentimiento generalizado que había suscitado la actual guerra contra el terrorismo. $\mathrm{Y}$ es que no solo se cuenta con la aceptación generalizada por parte de los Estados, sino que tanto la Resolución 1368 como la 1373 fueron aceptadas, como se ha apuntado por unanimidad ${ }^{33}$.

Los atentados del 11-S suscitaron en la sociedad internacional un interés y una preocupación sin parangón, y prueba de ello es la multitud de trabajos que desde las diferentes perspectivas han abordado el terrorismo, ya sea partiendo desde un punto de vista jurídico, político, económico o social. La reacción militar que suscitaron los atentados constituyeron un hito en la historia del Derecho internacional y un punto de referencia obligado, aunque no conviene olvidar que algo ya se había hecho por parte de otros Estados que de forma solitaria y con determinación tuvieron que hacer frente a diversos actos o ataques terroristas, invocando, eso sí, ya el derecho de legítima defensa.

Partiendo de estas premisas, la sociedad internacional se ha enfrentado al problema desde una perspectiva de prevención, de cooperación y de lucha contra esta lacra. Y es que nunca la comunidad internacional había padecido como hasta ahora el reto del terrorismo. No es extraño pues que hayan surgido cuestiones como las acciones preventivas, incluso armadas, como un medio de lucha más eficaz contra este enemigo invisible, pero presente y real, que no tiene fronteras y que ataca por sorpresa ${ }^{34}$. Así, la guerra antiterrorista, como señala Javier Jordán, deja de ser una guerra entre Estados, y pasa a desarrollarse entre estos y actores no estatales que crean redes temporales o permanentes ${ }^{35}$. Pero la guerra contra el terrorismo es además una guerra asimétrica y multidimensional, en donde el empleo de la fuerza militar es sólo uno más de los medios utilizados ${ }^{36}$.

Así pues, no es extraño que el terrorismo internacional fuera considerado como un gran desafío para la sociedad internacional en el ya muy comentado

33 Cfr. Bermejo GarCía, R., «El Derecho internacional frente al terrorismo: ¿nuevas perspectivas tras los atentados del 11-S?», op. cit., p. 22.

34 Esta ha sido proclamada urbi et orbi por los Estados Unidos, aunque también por Rusia.

35 Al-Qaida parece reunir a la perfección estas características de una red armada no estatal de alcance mundial con gran capacidad de acción.

36 Cfr. JORDAN, J., «El terrorismo y la transformación de la guerra. Consideraciones sobre la lucha global de Al-Qaida», Anuario de Derecho Internacional, 2004, pp. 408-424. 
y conocido, y para muchos sorprendente, Informe del Grupo de Alto Nivel sobre las amenazas, los desafíos y el cambio de 2 de diciembre de $2004^{37}$, adoptado a iniciativa del Secretario General de las Naciones Unidas, y que este hizo suyo en su Informe de marzo de 2005.

\section{LAS NUEVAS TENDENCIAS EN LA LUCHA CONTRA LOS DENOMINADOS GRUPOS ARMADOS NO ESTATALES: EL CASO DEL ESTADO ISLÁMICO}

La irrupción del denominado Estado Islámico en el tablero conflictivo mediooriental ha venido a poner sobre el tapete de la actualidad internacional el papel que pueden desempeñar los denominados actores no estatales en los conflictos armados, tanto a la hora de originarlos, en muchos casos ellos son los agentes principales o incluso los únicos, como a la hora de reaccionar contra los ataques que ellos llevan a cabo. Pero si se habla ahora sobre todo del Estado Islámico, esto se debe a sus especiales características ya que, aunque ahora ya esté debilitado, es una auténtica amenaza para el mundo dada su férrea estructura interna, sus medios financieros, su poder militar, sus conocimientos tecnológicos modernos a la hora de difundirlos, así como una propaganda envidiable ${ }^{38}$. El Estado Islámico ha llevado a cabo un riguroso adoctrinamiento de la población que se ha encontrado, o que se encuentra todavía, bajo su control territorial, aspecto este sumamente importante, pues ha ocupado partes importantes de Irak y Siria ${ }^{39}$. Es decir, en los territorios que ha ocupado, la población estaba obligada a cumplir con la Sharía en toda su extensión, persiguiendo, cuando no eliminando, a las minorías existentes,

37 Publicado con el título Un mundo más seguro: la responsabilidad que compartimos, Doc. A/59/565, se centra en el tema del terrorismo en las páginas 49-54, párr. 145-164.

38 El recurso a los nuevos medios de difusión como internet tanto para reclutar sus miembros como para difundir el terror ha sido una constante en el EI. Para más detalles, cfr. FARWELL, J.P., «The Media Strategy of ISIS», Survival: Global Politics and Strategy, 56, 2014, pp. 49-55; Klausen, J., «Tweeting the Fihad: Social Media Networks of Western Foreign Fighters in Syria adn Iraq», Studies in Conflict and Terrorism, 38, 2015, pp. 1-22.

39 A este respecto, cfr. GUTIÉRREZ ESPADA, C., «Choque de civilizaciones (el autoproclamado estado islámico). Respuesta de la comunidad internacional. ¿una 'alianza de civilizaciones' contra el estado islámico?», Anuario de los Cursos de Derechos Humanos de Donostia-San Sebastián, vol. XVI, 2016, pp. 111-213. El autor lleva a cabo en este trabajo un exhaustivo estudio de su creación, su configuración y los problemas que plantea para la comunidad internacional en materia de uso de la fuerza. 
como ha ocurrido con los yazidíes, cumpliendo así el famoso principio de que en el Islám todo es religión ${ }^{40}$.

Toda esta estructura paraestatal ha contado con amplios medios financieros y militares importantes debido a diversas causas como la venta de petróleo a Turquía, entre otras $\operatorname{cosas}^{41}$, o el armamento abandonado en su huida por las tropas iraquíes tratándose de los medios militares, tropas que se suponían bien entrenadas según recordaba en su momento el Presidente Obama y su Administración ${ }^{42}$, han hecho del Estado Islámico el actor no estatal por excelencia, al acaparar durante algún tiempo las competencias típicas de un Estado sobre sus territorios y ejercerlas como tales ${ }^{43}$. Con esto no queremos decir que el Estado Islámico fuera realmente un Estado, ya que no cuenta con los elementos fácticos y legales exigidos por el Derecho internacional ${ }^{44}$. Desbrozar esta

40 Sobre estos aspectos, cfr. Milliot, L., «La conception de l'Etat et de l'ordre légal dans l'islam», RCADI, 1949-II, p. 629. Ver también RECHID, A., «L'Islam et le droit des gens», RCADI, 1973-II, pp. 445 y ss.; y MAHMASSANI, S., «The Principles of International Law in the Light Islamic of Doctrine», RCADI, 1966-I, pp. 282 y ss. En donde se compara la «Jihad» con la «guerra justa» cristiana.

41 Otros medios financieros son los impuestos que impone a la población que está bajo su control, el dinero recaudado por el pago de los secuestros de extranjeros cuyos Estados pagan el rescate, el botín que ha obtenido en Irak y Siria atracando a los bancos, la venta de bienes culturales, las donaciones que recibe desde el extranjero, sobre todo, de árabes, etc. Para más detalles, cfr. GUTIÉRREZ ESPADA, C., «Choque de civilizaciones (el autoproclamado Estado Islámico...», op. cit., pp. 117-119.

42 La ingenuidad del Presidente Obama al pensar que el ejército iraquí ya era capaz de defender su territorio, y su decisión de retirar completamente las tropas estadounidenses de Irak en el año 2011 favoreció sobremanera la expansión del Estado Islámico. A este respecto, cfr., BYMAN, D. y WILliaMS, J., «ISIS vs. Al-Qaeda: Jihadism's global civil war», The National Interest, 24 febrero, 2015, p. 4. Así las cosas, una buena parte del armamento del ejército iraquí, en el que los estadounidenses habían invertido miles de millones de dólares, iría a parar al EI.

43 Sobre el origen y evolución del Estado Islámico, cfr. Pozo SERRANO, P., «El uso de la fuerza contra el Estado Islámico en Irak y Siria: problemas de fundamentación jurídica», Anuario Español de Derecho Internacional, vol. 32, 2016, pp. 144 y ss. Ver también LONGOBARDO, M., «The Self-Proclaimed Statehood of the Islamic State and International Law», Anuario Español de Derecho Internacional, vol. 33, 2017, pp. 205 y ss.

44 A este respecto, Marco Longobardo es claro, al señalar lo siguiente: «However, ISIS administration appears to lack effectiveness. Although the will of ISIS officials is normally enforced, the governmental powers'scope of application ratione personarum and ratione loci is not sufficiently stable to assess the effectiveness of the whole government. Due to continuing fights with the Iraqi, Syrian, and Kurdish armies and the international coalition's airstrikes, ISIS is unable to govern a portion of territory in a stable way. Rather, its powers are often just sporadic and the government apparatus shifts from area to area following the turns of the war. Stability is north a different criterion in and of itself, but rather, it is part of effectiveness. A governmental act, e.g. a law, cannot be effectively implemented if there is no continuity in the administration of a territory since may not be a court to enforce it when the need arises. In this respect, the obstacle 
cuestión es crucial para saber que uso de la fuerza se puede utilizar contra él, y cómo.

Pero si no es un Estado ¿qué es? ¿se trata de un grupo insurreccional? A nuestro entender, y siguiendo el pensamiento de la Profesora Pilar Pozo Serrano, tampoco el EI sería un grupo insurreccional, y lo señala en los términos siguientes:

«La naturaleza del Estado Islámico no responde propiamente a la de un movimiento insurreccional iraquí, que pretende desplazar al gobierno en el poder. Se trata, de un grupo terrorista incluido como tal en listas elaboradas por Estados y organizaciones internacionales. Al mismo tiempo no es un fenómeno meramente interno: desarrolla actividades fuera de las fronteras iraquíes, cuenta con bases de operaciones en territorio sirio, donde se refugia y desde donde efectúa ataques contra Irak y sus objetivos trascienden el conflicto en Irak» ${ }^{45}$

Distinta es la opinión del Profesor Marco Longobardo, quien a este respecto afirma que el EI parece ser «un grupo insurreccional» ${ }^{46}$.

Así las cosas, la doctrina lo ha considerado como uno de esos actores no estatales, o lo que es lo mismo uno de esos grupos armados que pululan últimamente más que nunca. Pero el Estado Islámico no es solo un actor no estatal bien armado que se extendió como un reguero de pólvora, sino que es además una organización terrorista, calificación que lo demuestran las

to ISIS statehood is not the fact that its territory is not precisely defined, a circumstance which does not affect the international personality of already established States, but rather the fact that it is totally unclear what territory is claimed, since ISIS control changes greatly daily and there is no historical title that can be uses as a reference. Consequently, for the time being, ISIS lacks effective government and therefore, statehood». Cfr. LONGOBARDO, M., «The Self-Proclaimed Statehood of the Islamic State...», op. cit., p. 218.

45 Cfr. POZO SERranO, P., «El uso de la fuerza contra el Estado Islámico...», op. cit., p. 158.

46 Este autor afirma que «In light of these factual elements, ISIS appears to be an insurrectional group. Insurgents are international subjects that exercise de facto powers over a territory but are provisional in character since they are doomed to be quelled and disappear if their outcome is not the formation of a new State. This is the ISIS scenario: its administration is provisional in the sense that it is not stable, and, therefore, ISIS cannot be considered a State. Due to its relative scarcity of men, ISIS is like an oil spill in the sea: it reaches many far areas, but in doing so it is losing consistence, i.e. control over certain zones, since its army cannot control at the same time all the areas where the hostilities are conducted; therefore, there are many gaps in the structure of ISIS territory, and many others are created every time ISIS is forced to loosen its ranks in order to move troops to conquer other positions. By contracts, if ISIS consolidate its power over a delimited area and its inhabitants, then it could claim to be a State according to he factual theory». Cfr. LONGOBARDO, M., «The Shelf-Proclaimed Statehood of the Islamic State and International Law», op. cit., p. 219. 
atrocidades cometidas, pero es que además el propio Consejo de Seguridad así la ha calificado en numerosas ocasiones en sus resoluciones ${ }^{47}$. Es más, a pesar de que hoy en día no mantiene vínculos estrechos con la organización Al-Qaeda, el EI ha destronado a esta última organización del podio de las organizaciones más crueles y feroces, atrayendo combatientes de todo el mundo, países occidentales incluidos, pero también de Rusia, sobre todo chechenos $^{48}$. Así pues, con el fin de consolidar su control territorial tanto en Irak como en Siria, no ha dudado en recurrir al terror y a las graves violaciones de los derechos humanos ${ }^{49}$. En el ámbito religioso, las minorías religiosas, incluidas los chiitas, han sido perseguidos, destacando en este caso, como ya se ha apuntado, la persecución a la secta de los yazidíes, muchos de los cuales han sido masacrados, mientras que las mujeres eran condenadas a ser esclavas sexuales. Si a todas estas atrocidades añadimos el entorno geográfico y político en la zona (conflicto en Siria, caos en Irak, el tema israelo-palestino, la guerra en Yemen, etc.) era obvio que, de una forma o de otra, las potencias extranjeras, sobre todo aquellas con intereses en la zona, iban a intervenir. Pero la cuestión era saber sobre qué bases jurídicas podían llevar a cabo esas intervenciones y es este el tema que vamos a analizar en las próximas páginas. Antes queremos dejar claro, no obstante, que debido a los conflictos e intereses en la zona, a lo que hay que añadir los ataques terroristas que han tenido lugar en Europa ${ }^{50}$, al amparo, o al menos reivindicados por el EI, los Estados han ido invocando diversas figuras jurídicas a medida que se iban desarrollando los acontecimientos, aunque de una forma en algunos casos no muy clara. En nuestra opinión, el país que ha sabido

47 Véase por ejemplo las Resoluciones 2170 y 2178 de 2014, así como las Resoluciones 2199 y 2249 de 2015. A este respecto, cfr. infra.

48 Según diversas fuentes, unos tres mil combatientes chechenos se han enrolado en el EI, y algunos de ellos ya se han destacado por su crueldad.

49 Sobre las violaciones de los derechos humanos, véanse los informes siguientes: Report of the Independent International Commission of Inquiry on the Syrian Arab Republic, rule of Terror: Living under ISIS in Syria, UN Doc. A/HRC/27/CRP.3 (2014); Report of the Office of the United Nations High Commissioner for Human Rights on the Human Rights Situation in Iraq in Light of the Abuses Committed by the So-Called Islamic State in Iraq and the Levant and Associated Groups, UN Doc. A/ HRC/28/18 (2015); Report of the Office of the United Nations High Commissioner for Human Rights on the Human Rights Situation in Iraq in the Light of Abuses Committed by the So-Called Islamic State in Iraq and the Levant and Associated Groups, UN Doc. A/HRC/28/18 (2016).

50 Hablamos de los ataques terroristas en Europa, pero sin olvidar los numerosos ataques, y mucho más mortíferos, cometidos en otros países, como por ejemplo Irak, Nigeria o Pakistán, por poner solo algunos ejemplos. 
tener una línea coherente en los conflictos de la zona, y también en el caso del EI en Siria ha sido Rusia ${ }^{51}$, cuyo Ministro de Asuntos Exteriores, Serguei Lavrov, no solo habla muy claro, sino que sabe lo que dice, lo que no ocurre en muchos otros casos.

Pero si el EI es sin lugar a dudas el actor no estatal armado que ha planteado más problemas a la comunidad internacional al controlar, al menos temporalmente, ciertos territorios y establecer una estructura paraestatal, por oposición a Al-Qaeda, hay que insistir sobre el hecho de que no es el primero. Es más, el número puede ir incrementándose en el futuro, a la luz de los problemas que se están detectando en otras zonas, como en África o en Asia. Pero dejando al margen esta cuestión, un grupo armado que presenta en el terreno político y militar, no tanto en el religioso, muchas similitudes con el EI, es Hezbolláh y, a su análisis, nos detendremos en las siguientes páginas.

\subsection{El Grupo Hezbolláh y sus similitudes con el EI}

En efecto, un actor no estatal, configurado como grupo armado, y calificado por algunos Estados como terrorista, es también Hezbolláh, asentada en el sur del Líbano en cuyo territorio es dueña y señora, siendo conside-

51 Como se sabe Rusia, un gran aliado del régimen sirio como lo fue antaño la Unión Soviética, autorizó y empezó a atacar objetivos y posiciones de los grupos armados que luchaban en el entorno de la ciudad siria de Homs contra las tropas del régimen de Al-Assad, y con el consentimiento expreso de éste. Entre esos grupos se encontraba el EI, así como otros grupos rebeldes, algunos de ellos pro-occidentales. Tras seis meses de intervención, el Presidente Putin ordena la retirada del grueso de las tropas el 14 de marzo de 2015, tras conseguir los objetivos que se habían marcado. Esta intervención rusa cambió en ciento ochenta grados el rumbo del conflicto, pasando las tropas gubernamentales sirias de estar acorraladas y a la defensiva, a tomar las iniciativas militares, como se vería después también en Alepo. La sorpresa de los países occidentales que muchos de ellos pasaron a considerar que Al-Assad ya no era solo parte del problema, sino también de la solución. Desde esta perspectiva, las frases rimbombantes y contrarias a Al-Assad que había lanzado el por aquel entonces nuestro Ministro de Asuntos Exteriores, García Margallo, entre otros, cambiaron no solo de orientación, sino también de tenor literal. Y es que la Diplomacia no siempre está reñida con la fuerza, pero cuando esto ocurre la fuerza prevalece: es decir, como dijo el famoso Karl Von Clausewitz, «la guerra es la continuación de la política por otros medios», con otras muchas muy interesantes que figuran en su libro «De la Guerra», que comprende ocho libros. Sobre la intervención militar rusa en Siria, cfr. JORDÁN ENAMORADO, J., «La intervención militar de Rusia en Siria: oportunidades y riesgos», IEEE, Documento Marco 27/2015, de 27/10/2015, pp. 1-22. Ver también, LABORIE IGLESIAS, M., «La Estrategia de Seguridad Nacional de la Federación Rusa (diciembre 2015)», IEEE, Documento de Opinión 25/2016, 11 de marzo de 2016, pp. 1-11. 
rada de forma muy generalizada como la mayor protectora de la población libanesa contra Israel. Es cierto que participa directamente en el Gobierno libanés, pero no es el gobierno del Estado libanés. Hezbolláh cuenta también con abundantes recursos financieros, así como con medios militares importantes proporcionados sobre todo por Irán, pero contando además con el apoyo de Siria. Tanto es así, que en el conflicto sirio, las milicias de Hezbolláh se han convertido en algunas batallas en la punta de lanza de las tropas de Al-Assad. Una diferencia importante con el EI es, sin embargo, la religiosa, no solo porque Hezbolláh sea chiita y el EI suní, sino porque no se tiene conocimiento de que Hezbolláh haya cometido atrocidades contra las minorías religiosas ni incluso que las haya perseguido. Es sabido que en el Líbano la convivencia religiosa entre cristianos, drusos y musulmanes suníes y chiíes ha sido la tónica general, salvo en algunos duros momentos, como durante la guerra civil libanesa, aunque también es cierto que la que fue denominada otrora la Suiza del Medio oriente dista mucho de honrar esa expresión.

Dicho esto, si traemos aquí a colación este actor no estatal, como es esta organización armada y política como es Hezbolláh, es porque en algunos aspectos, sobre todo los militares y territoriales, comparte con el EI determinadas características. Si desde el punto de vista territorial su control de facto del sur del Líbano es bien conocido desde hace tiempo ${ }^{52}$, no lo era tanto su capacidad militar, por lo menos tal y como ocurrió en la denominada Guerra de los 33 días, que enfrentó a Israel y a Hezbolláh en el Líbano, y que produjo mil doscientos muertos en el Líbano, entre ellos seis cientos milicianos de Hezbolláh, y ciento cuarenta y nueve del lado israelí.

Pero este conflicto no surgió de la nada, como tampoco ha ocurrido esto con el EI. En efecto, la gestación de esta organización arranca ya en 1982, año en el que el Gobierno israelí decide la invasión del Líbano, y con ella el inicio de una operación que, dirigida por el audaz General Ariel Sharon, alcanzaría Beirut, obligando así a las fuerzas palestinas a exiliarse con su líder, por aquel entonces Yasser Arafat, a Túnez. Sin embargo, a pesar

52 A este respecto el autor Walid Charara publicó en árabe una obra con el título El Estado de Hezbolláb: el Líbano como sociedad islámica, Dar Al Nahar, Beirut, 1996. De este mismo autor, cfr. Le Hezbolláb: Un mouvement islamonationaliste, Fayard, Paris, 2004. Sobre Hezbolláh, véase también Hezbolláh as a Case Study of The Battle for Hearts and Minds, Intelligence and Terrorism. Information Center at the Israel Intelligence Heritaje X Commemoration Center (IICC), Junio 2007, $112 \mathrm{p}$. 
de que sus actividades eran bien conocidas de los israelíes, la organización como tal solo fue proclamada en 1985. Aunque uno de sus objetivos era luchar contra las fuerzas israelíes que por aquel entonces ocupaban el sur del Líbano, nadie pone en duda que se creó con la ayuda de Irán, tanto a nivel político, como ideológico, pero también desde el punto de vista militar y financiero, permitiéndole así adquirir una posición hegemónica en el seno de la comunidad chiíta libanesa. La organización salió además muy reforzada tras ordenas Ehud Barak, por aquel entonces Jefe del Gobierno israelí, la retirada de la zona en mayo del año 2000, al atribuirse este hecho como una victoria propia. Tanto es así que, a partir de entonces, la organización controlaba todos los hilos del poder en la zona, funcionando como un «subestado» en el seno del Estado libanés. Así las cosas, la organización fue adoptando un modus operandi que la llevaría progresivamente a la confrontación y a la guerra con Israel. Así las cosas, la chispa del conflicto podía saltar en cualquier momento.

En efecto, el conflicto directo con Israel se iniciaría el 12 de julio de 2006, tras haber matado los miembros de Hezbolláh a ocho soldados israelíes, al mismo tiempo que secuestraban a dos dentro del territorio israelí. Todo apunta a que el ataque estaba ya pensado y, por lo tanto, fue premeditado, ya que según apunta el autor libanés Gilbert Achcar, Hezbolláh empezó a preparar la toma de rehenes, de soldados israelíes ya en marzo de 2006, según una declaración que hizo el propio líder de la organización, Nasrallah, el mismo día del desencadenamiento del conflicto ${ }^{53}$. El momento del ataque también fue arriesgado, pues Israel estaba llevando a cabo en esos momentos una operación de envergadura en Gaza a razón del secuestro de otro soldado, abriéndose así dos frentes: el del Norte y el del Sur ${ }^{54}$.

El desarrollo del conflicto, que tuvo lugar durante 33 días, no fue fácil para ninguna de las partes ${ }^{55}$, ya que las fuerzas israelíes se vieron en muchos

53 A este respecto, y para más detalles, cfr. ACHCAR, G. y WARSCHWSKI, M., La guerra de los 33 días. Israel contra Hezbolláh en el Libano y sus consecuencias, Icaria, Barcelona, 2006, pp. 41-42.

54 Para más detalles véase, BEN-AMI, S., «Los dos frentes de Israel», Política Exterior, n 114, 2006, pp. 113 y ss.; y BERMEJO GARCÍA, R., «Israel en dos frentes: algunas cuestiones jurídico-políticas en torno a la desconexión de Gaza y a la guerra de Hizbollandia», en RAMÓN CHORNET, C., Los conflictos armados y el Derecho internacional humanitario. Problemas actuales, PUV, Valencia, 2008, pp. 171-2010.

55 Sobre el conflicto, cfr. Dubuisson, F., «La guerre du Liban et le droit de légitime défense», Revue belge de droit international, 2006, pp. 562 y ss. En este estudio se sigue defendiendo la tesis clásica en materia de legítima defensa. 
casos sorprendidas por milicianos de Hezbolláh bien preparados desde el punto de vista militar, y con una moral alta. De parte israelí, hay que reconocer que no fue una campaña militar como otras a las que nos tiene acostumbrados Israel, y las críticas al Gobierno y a los altos mandos militares estuvieron en el orden del día, sobre todo al jefe del Estado Mayor, Dan Halutz. El famoso Informe Winograd puso de manifiesto los fallos en la cadena de mando del Tsahal, debido a lo cual rodaron algunas cabezas. No obstante, y a pesar de todo esto, hay que reconocer que aproximadamente un tercio de los militantes de Hezbolláh que participaron en los combates perecieron y que, al final, las tropas israelíes se presentaron en el río Litani, objetivo final de la respuesta armada. Si a esto añadimos el hecho de que sobre la base de la Resolución 1701, de 11 de agosto de 2006, por la que se adopta el cese el fuego, se refuerza la FINUL de forma considerable, con el fin de impedir de que haya contacto directo entre Hezbolláh e Israel, todo parece apuntar a que los grandes objetivos del Tsahal, más o menos, se cumplieron.

El conflicto no le saldría tampoco gratis a Hezbolláh, y no se puede decir que saliera tan victoriosa como algunos pretenden. Basta con centrarse en las propias declaraciones del líder Hassan Nasrallah para comprender el infierno de la guerra desatada en el Sur del Líbano y Norte de Israel, cuando declaró tajantemente el 28 de agosto de 2006, es decir dos semanas después del cese el fuego, que se lo pensaría mucho antes de lanzar un nuevo ataque. El jefe de Hezbolláh reconoció de forma honrada su error de cálculo de la manera siguiente:

«No habíamos previsto, ni de lejos, que la toma de rehenes iba a conllevar una guerra de esta envergadura. ¿Por qué? Debido a la experiencia de varios decenios y porque sabemos cómo el israelí actúa, no era posible que una reacción a una toma de rehenes alcanzara tales proporciones, sobre todo en temporada turística. En la historia de las guerras, nunca ha ocurrido que un Estado entre en guerra contra otro Estado por unos soldados arrestados y otros muertos. Ahora, si me pregunta (lo que hubiéramos hecho) si hubiera sabido que este secuestro iba a conllevar una guerra de esta dimensión con un porcentaje de probabilidades alto, pues bien no lo habríamos hecho con toda seguridad, y ello por razones humanas, morales, militares, sociales, de seguridad y políticas ${ }^{56}$.

56 Cfr. Texto recogido en la prensa israelí, y citado por ACHCAR, G. y WARSCHAWSKI, M., La guerra de los 33 días..., nota 357, op. cit., pp. 42-43. 
Algo de esto estaba también presente en la mente del Jeque Ali Al-Amin, Mufti chiíta libanés de Tiro, quien después de criticar abiertamente a Hezbolláh por su conducta durante el conflicto, dijo el 26 de agosto lo siguiente:

«Con respecto a la victoria de [Hizbolá] tal y como esta la ha llamado, no creo que fuera tal victoria... No quiero entrar en discusión sobre el significado de lo que es victoria, pero yo pregunto: ¿Estábamos nosotros en tal estado de derrota antes del 12 de julio que necesitábamos de tal 'grande' y 'estratégica' victoria después del 12 de julio? $\gg^{57}$

Así las cosas, quizás haya que decir con la autora israelí Rina Erak, que «todos hemos perdido la última guerra del Líbano. No obstante, no conviene sacar las cosas de quicio. Ni el Líbano ni Siria se han movido con el fin de buscar una guerra abierta con Israel, ya que sabían que estaban en el punto de mira de las fuerzas israelíes y conocen por propia experiencia cómo se las gasta el Tsahal en esa clase de situaciones. Pretender ahora que una organización como Hezbolláh pueda derrotar militarmente a Israel, por mucha ayuda que cuente de Irán y Siria, es desconocer el poderío militar israelí y su capacidad de respuesta.

\subsection{Algunas cuestiones jurídicas en torno el conflicto: ¿Podría ejercer Israel el derecho a la legítima defensa?}

Pero este conflicto iba a poner sobre la mesa una serie de cuestiones desde el punto de vista jurídico, alguna de las cuales, como saber si Israel tenía el derecho a defenderse, es decir el derecho de legítima defensa, era sumamente importante para reforzar o no esas nuevas tendencias que de forma clara se van confirmando tras los atentados del 11-S. Desde este prisma, y vistas las características del conflicto, ¿se puede hablar de un derecho de legítima defensa de Israel según el derecho consuetudinario o según el artículo 51 de la Carta de las Naciones Unidas? La respuesta a esta cuestión requiere partir de las dos afirmaciones siguientes: a) como se sabe, el artículo 51 de la Carta no determina expressis verbis que el ataque armado debe proceder de un Estado; y b) un ataque de esa consideración es en nuestra opinión un uso grave de la fuerza,

57 Cfr. The Middle East Media Research Institute (MENRI), Despacho Especial n ${ }^{\circ} 1295$. El mismo Muti chiíta libanés volvía a la carga el 5 de septiembre, diciendo que: «Nosotros no podemos clamar que el enemigo ha sido derrotado. El enemigo tenía también metas que no pudieron cumplirse, pero no existe ninguna comparación entre nuestro dolor y el del enemigo... Nosotros sufrimos más que nuestro enemigo... y la destrucción causada aquí fue mayor que la causada a nuestro enemigo...», ibid. 
tal y como dijo la CIJ en el Asunto de Nicaragua. Y es que para la Corte, tal y como pone de relieve en este Asunto, si el ataque fuera sólo «leve» no cabría el derecho de legítima defensa, aunque se podría invocar la responsabilidad internacional o adoptar otras medidas. El problema de esta afirmación de la Corte es que no específica cuando se está ante un ataque «grave» ni cuando es «leve». La distinción, no obstante es retomada por la Corte en el Asunto de las plataformas petrolíferas entre Irán y los Estados Unidos, del 6 de noviembre de 2003, aunque sigue siendo vaga a la hora de determinar el umbral de gravedad del ataque ${ }^{58}$. Mayor precisión, aunque no mucha tampoco, ha introducido el Instituto de Derecho Internacional, al recoger en su Resolución 10 A del 27 de octubre de 2007, pár. 5, adoptada en la sesión de Santiago de Chile, que el ataque debía revestir un «cierto grado de gravedad», expresión que mitiga por un lado y precisa por otro las expresiones de la Corte.

Por otro lado, se da la circunstancia en el caso que nos ocupa de que los ataques contra los que Israel invoca la legítima defensa no provienen de un Estado sino de un grupo armado no estatal, y se da la circunstancia de que la Corte sólo ha reconocido hasta ahora la legítima defensa frente a los ataques de Estados o en caso de agresión indirecta cometida por los Estados, a lo que hace alusión la conocida Resolución 3314 de la Asamblea General de 1974. Es más, en el asunto de las Actividades armadas sobre el territorio del Congo, de 11 de diciembre de 2005, que oponía este país a Uganda, la Corte tuvo una ocasión de oro para pronunciarse, ya que se le pedía «si et à quelles conditions le droit internacional contemporain prévoit un droit de légitime défense pour riposter à des attaques d'envergure menées par des forces irregulières», cosa que no hizo, suscitando así acerbas críticas de los jueces Kooijmans y Simma en sus opiniones disidentes $^{59}$, al estimar que la Corte debía haber aprovechado esta ocupación para pronunciarse según ellos favorablemente sobre esta cuestión.

Pero si la Corte ha guardado silencio sobre el tema, el Instituto de Derecho Internacional ha dado en la Resolución ya citada 10 A, un paso adelante al reconocer que:

«En cas d'attaque armée d'un Etat par un acteur non étatique, l'article 51 de la Charte, tel que complété par le droit international coutumier, s'applique en principe»

58 Cfr. Recueil, pp. 191-192, par. 64 y p. 145, par. 72. A este respecto, ver también la sentencia de la Comisión Eritrea/Etiopía sobre el ius ad bellum, de 19 de diciembre de 2005.

59 A este respecto, cfr. los par. 20 y ss.; y par. 4 y ss. respectivamente. 
Sin embargo, afirmado el principio, la Resolución del Instituto dice en la segunda frase que se han examinado un determinado número de casos de ataques armados llevados a cabo por actores no estatales, y que algunas respuestas preliminares a los problemas complejos que plantean estos casos podrían ser los siguientes:

(i) Si des acteurs non étatiques lancent une attaque armée sur les instructions, la direction ou le contrôle d'un Etat, ce dernier peut devenir l'objet de l'action en légitime défense de l'Etat visé.

(ii) Si une attaque armée par des acteurs non étatiques est lancée depuis un espace situé hors la juridiction de tout Etat, l'Etat visé peut exercer son droit de légitime défense dans cet espace contre ces acteurs non étatiques.

El apartado (i), no introduce novedad alguna. Por el contrario, el contenido del apartado (ii) es novedoso, y da un paso más que la Corte Internacional de Justicia, pues aquí ya se afirma que puede haber derecho de legítima defensa sin que el ataque armado proceda de un Estado. Dicho esto, lo lógico hubiera sido que el Instituto de Derecho Internacional hubiera continuado su hilo conductor reconociendo expresamente, y no sólo «en principio», el derecho de legítima defensa frente a estos ataques aunque procedieran de territorios sujetos a la jurisdicción o soberanía de un Estado. Es decir, a nuestro entender las frases comprendidas en las letras (i) e (ii) precitadas parecen limitar el alcance de la frase primera en donde se reconoce que el derecho de legítima defensa se aplica en principio. Se ha desaprovechado, pues, una buena ocasión para, al menos a nivel teórico, dilucidar completamente una cuestión que ha planteado y, ahora más que nunca, serios problemas. No obstante, esto no es óbice para reconocer que ya la frase primera precitada del párrafo $10 \mathrm{de}$ la Resolución comentada es un paso de gigante.

En el caso que estamos comentando ahora, no cabe atribuir el ataque de Hezbolláh al Estado libanés, salvo que se considere que es responsable del mismo en tanto que no hizo nada por controlar el territorio o impedirlo. ¿Es esto suficiente para poderle atribuir el ataque en sí? No lo creemos, pero eso no implica que el Estado atacado no tenga el derecho a defenderse ${ }^{60}$. En el caso que nos

60 Sobre estos aspectos, cfr. HARTWIG, M., «Wich State’s Territory May Be Used for Self-Defence Against Non-State Actors?», en PETERS, A. y MARXSEN, Ch. (eds.), Self-Defence Against Non-State Actors: Impulses from the Max Planck rialogues on the Law of Peace and War, Zaörv, 2017, pp. 39-41. 
ocupa los Estados europeos han reconocido el derecho a defenderse de Israel tras el ataque, así como la propia UE, y por supuesto los Estados Unidos ${ }^{61}$. Respecto al G-8, en su reunión del 17 de julio se pronunció por el cese de las hostilidades entre las partes y por el envío de una fuerza multinacional de las Naciones Unidas, pero omitiendo hablar del uso desproporcionado de la fuerza por parte de Israel, algo en lo que insistían países como Francia y Rusia ${ }^{62}$, sin olvidar la UE. Por lo tanto, si ha habido recriminaciones a Israel han sido por un eventual uso desproporcionado de la fuerza, pero no por recurrir al derecho a defenderse.

Desde esta perspectiva, no se puede exigir en nuestra opinión a un Estado lo imposible, es decir quedarse con los brazos cruzados frente a grupos armados por el mero hecho de que no se pueda imputar claramente el ataque a ese Estado, sobre todo cuando ese ataque es de una determinada consideración y cuando se sabe que el Estado desde cuyo territorio procede el ataque no hará nada bien porque no pueda, como era este el caso, o bien porque no quiera ${ }^{63}$. En un mundo en el que tenemos bastantes Estados fallidos y grupos armados u organizaciones más poderosos que los Estados en los que se encuentran o desde el que actúan, negar el derecho «inherente» o «natural» a defenderse podría poner en peligro la supervivencia de algunos Estados. Así las cosas, todo parece indicar que los Estados son conscientes de ello, y propugnan o defienden ese derecho de legítima defensa de una manera más amplia que la propia CIJ. Es obvio que se puede predicar en el desierto, pero el resultado es el que es, y en esto los Estados, cuando a ellos les toca, no están dispuestos a renunciar a la única herramienta jurídica de la que dispone en el ámbito del Derecho internacional como es el derecho de legítima defensa en caso de ataque. En realidad, nada nuevo bajo el sol y vuelta a empezar...

Desde que se adoptó la Resolución 1701 del Consejo de Seguridad de 2006, la frontera libanesa ha continuado estando muy vigilada por Israel, habiendo reforzado las fuerzas allí presentes, haciendo ver que una nueva guerra con Hezbolláh no se desarrollaría en las mismas condiciones que la de 2006. Por eso Israel no ha dudado en atacar tanto en el Líbano como en Siria

${ }^{61}$ Cfr. La Razón de 18 de julio de 2006, p. 24. Tan sólo el Presidente del Gobierno español se abstuvo de condenar los ataques de Hezbolláh, algo que sí que hicieron, sin embargo, la Vicepresidenta del Gobierno y el Ministro de Asuntos Exteriores.

62 Cfr. Le Temps (Ginebra) de 18 de julio de 2006. Ver también la Declaración del G-8.

63 Para un análisis dde estos dos conceptos, cfr. CHRISTAKIS, T., «Challenging the 'Unwilding or Unable' Test», en Peters, A. y MARXSEN, Ch. (eds.), Self-Defence Against Non-State Actors..., op. cit., pp. 17-20. 
cualquier entrega de armas cuyo destino fuera Hezbolláh ${ }^{64}$. Es más, la fuerza aérea israelí ha continuado incluso siendo más activa a este respecto durante el conflicto civil que padece Siria desde el año 2011, a causa sobre todo de la participación muy activa en el conflicto tanto por parte de Hezbolláh como de Irán, atacando convoyes de armamento que, según Israel, estaban destinados a Hezbolláh, lo que prohíbe la Resolución 1701, antes analizada. Sin embargo todo apunta a que esto no ha sido suficiente para impedir el rearme de Hezbolláh en el Líbano que según muchas fuentes, incluso las israelíes, es ahora más fuerte que nunca, generando así mucha desconfianza en Israel que se preparan para una nueva guerra, llegado el caso.

Es evidente que el conflicto sirio ha servido de acicate para las fuerzas de Hezbolláh y les ha dado una imagen de un grupo armado consistente y sólido, lejos del fanatismo del EI y del sello que tiene como organización terrorista. Desde esta perspectiva no es extraño que según el New York Times del 27 de agosto de 2017, Hezbolláh ha ido evolucionando de una organización terrorista hacia una milicia internacional conducida por Irán. El autor del artículo, Ben Hubbard, señala además que este actor no estatal tiene un completo control político y militar sobre el Líbano, afirmando que «is not just a power unto it self, but is one of the most important instruments in the drive for regional supremacy by ist sponsor, Iran». Es más, Hezbolláh es el componente principal para establecer un corredor que vaya desde la frontera iraní hasta Siria y el Líbano, formando así una especie de arco en torno al Mediterráneo. Y es que Hezbolláh no solo combate, sino que está llevando a cabo un reclutamiento y entrenamiento de numerosos nuevos militantes, poniéndolos a disposición de Irán. Así las cosas, no es extraño que el líder de Hezbolláh, Hassan Nasrallah señalara ya en junio de 2017 que miles de combatientes vendrían a luchar con Hezbolláh en la futura guerra con Israel. «This could open the way for thousands, even hundreds of thousands of fighters from all over the Arab and islamic world to participate-from Irak, Yemen, Iran, Afganistan and Pakistan...», tal y como indicó en el mensaje televisivo. Así las cosas, negar el derecho de legítima defensa a un Estado para defenderse de una organización más poderosa que muchos Estados, nos parece de ciencia ficción, y de una gran ingenuidad, ya que no es realista.

64 Como se sabe Israel también atacó en Siria una instalación nuclear en la noche del 6 de septiembre de 2007, en la región de Day az-Zawr, en la Operación Huerto, en la que se estaba construyendo un reactor nuclear por Corea del Norte, causando la muerte de diez técnicos norcoreanos. Esta Operación parece que contó con la aprobación de los Estados Unidos, o al menos sí que fueron informados. 
Por eso, en la lucha contra el terrorismo, el mundo empieza a darse cuenta de cómo Israel ha sabido hacer frente al terrorismo desde el mismo día de su creación, es decir, hace ya 70 años, con constancia y coraje, basándose en la premisa de que «el terror es terror». No es extraño, pues, que algunos pongan sus ojos en este pequeño país cuando, en relación con el terrorismo que se está desarrollando ahora en Europa se preguntan cómo ha hecho frente a esta lacra. Tal es el caso del periodista británico. David Patrikarakos, que en el periódico The Spectator, del 20 de agosto de 2017 señalaba lo siguiente:

«We are fighting $21^{\text {st }}$ century terrorists with $20^{\text {th }}$ century methods. Nonetheless, more can, and must be done. One country above all, has the method and the solution: Israel... This little country of light million has been dealing with terrorism since the state's inception 70 years ago... From airline hijackings to suicide bombers to stabbings, shooting and vehicle attacks, Israel has seen them all-and has adapted accordingly $\gg^{65}$.

Esta realidad existente sobre el terreno ha sido objeto de la Resolución 2373 del Consejo de Seguridad, adoptado el 30 de agosto de 2017 por unanimidad, en la que se expresa la preocupación «por el escaso progreso realizado respecto del establecimiento de un alto el fuego permanente, y otras disposiciones clave de la Resolución 1701 (2006) más de diez años después de su aprobación». Se reconoce, pues, un cierto fracaso en la aplicación de la Resolución 1701, lo que es evidente por otro lado, sobre todo en todo lo que atañe a la prohibición de la venta y el suministro de armas y material conexo, algo que estaba recogido que no podía llevarse a cabo sin la autorización del Líbano ${ }^{66}$.

Sin embargo, ha habido un hecho importante que está detrás de la adopción de esta Resolución, y es la presión de la nueva Embajadora estadounidense ante las Naciones Unidas, Niki Haley, la que tras visitar la frontera israelí con el Líbano, y habiendo sido informada de la falta de eficacia de las fuerzas de la ONU (UNIFIL, por sus siglas en inglés), aprovechando que había que negociar la prórroga de dicha fuerza, solicita que se revisen los planteamientos por los que actúan con el fin de dotarla de mayor eficacia para que cumpla con su misión ${ }^{67}$. Por

65 Ver también The Algemeiner, 22 de agosto de 2017, el artículo «After Latest Islemist Terror Atrocity in Europe, Israel Touted as Example to Emulate on Security».

66 Se está pensando en Hezbolláh.

67 A este respecto, cfr. «Harirí: Israel ment sur les usines d'armes du Hezbolláh au Liban», The Times of Israel, 3 de septiembre de 2017; «UN Security Council Toughens in Libanon to Disrupt Hezbolláh Activity», The Tower, 31 de agosto de 2017; y «Security Council resolution to combat Hezbolláh a 'Victory for Israel'», World Israel News, 31 de agosto de 2017. 
eso, el párrafo 8 de esta Resolución «reafirma la necesidad de que se realice un despliegue eficaz y duradero de las fuerzas armadas libanesas en el sur del Líbano y en las aguas territoriales libanesas a un ritmo acelerado para aplicar plenamente las disposiciones de la Resolución 1701...». Y es que en la zona sigue Hezbolláh controlando el territorio de facto. Sin embargo, hay que resaltar que la resolución no menciona expresamente a Hezbolláh, a pesar de que implícitamente está presente en todo el texto. Este clamoroso silencio se debe a la amenaza rusa de oponer su veto a esta resolución si Hezbolláh era citada ${ }^{68}$.

Conviene apuntar además que a las tesis de la Embajadora estadounidense se oponían abiertamente tanto Francia como Italia, países que son los que proporcionan más fuerzas a la FINUL. Y es que según la representante francesa, Anne Guegen, no se debía tocar el delicado equilibrio existente actualmente en el sur del Líbano, mientras que el representante italiano, Sebastiano Cardi señalaba que no había que mezclar los deberes de las fuerzas de la FINUL con aquellos que corresponden a las fuerzas libanesas. Dicho esto, es evidente que la Resolución refleja las tesis estadounidenses al recoger el reconocimiento de que el Consejo de Seguridad avala un cambio necesario en la FINUL para que pueda ser eficaz y cumplir con los objetivos que son impedir que Hezbolláh refuerce su arsenal militar ${ }^{69}$.

\section{LAS MEDIDAS ADOPTADAS POR LA COMUNIDAD INTERNACIONAL \\ ANTE LOS RETOS PLANTEADOS POR EL EI: A VUELTAS CON \\ LA LEGÍTIMA DEFENSA, Y CONFIRMACIÓN POR LA PRÁCTICA ESTATAL DE LAS NUEVAS TENDENCIAS}

La lucha contra el EI se ha ido desarrollando por unos derroteros engorrosos, debido sobre todo a los distintos intereses que muchos Estados tenían y tienen en la zona. Y es que el EI no solo representa desafíos importantes para Irak o Siria, parte de cuyos territorios iba a ocupar, sino también para el

68 Para más detalles, cfr. SURKES, S., «La Russie aurait menacé d'opposer son veto au mandat de la FINUL si le Hezbolláh était cité», The Times of Israel, 5 de septiembre de 2017. Ver también «Days after Netanyahu-Putin Meeting, Russia Threatened to Veto anti-Hezbolláh Move Led by Israel and US at UN», Haaretz 5 septiembre de 2017.

69 Para Israel, la adaptación de esta resolución ha sido considerada como un éxito contra Hezbolláh, al aprobar un mandato más sólido para la FINUL. A este respecto, cfr. «Israel salue le renouvellement du mandat des Casques bleus au Liban», The Times of Israel, 2 septiembre de 2017. 
resto de países de la zona como Jordania, el Líbano o Turquía, pero incluso también para Arabia Saudí, país que, sin embargo, los ha venido condenando casi siempre de boquilla, e incluso con una cierta sonrisa, sin olvidar a Qatar. Cabe pensar que si Arabia Saudí hubiera adoptado desde los inicios del EI actitudes tajantes de condena, quizás la sociedad internacional hubiera ahorrado muchas conferencias internacionales, muchos quebraderos de cabeza y, por qué no, quizás también muchos atentados. Esta pasividad saudí y el hecho de que muchos de esos atentados se hayan cometido contra chiís, sobre todo en Irak, ha atizado sin lugar a dudas la rivalidad en la zona entre Arabia Saudí e Irán que, como se sabe, está también presente en el conflicto sirio ${ }^{70} \mathrm{e}$ incluso en el Líbano. Pero también tenemos una rivalidad en la zona entre Irán y Turquía, ahora mitigada a raíz de la intervención rusa en el conflicto sirio desde septiembre de 2015, y esa rivalidad ha persistido también entre los Estados Unidos y Rusia, aunque más que rivalidad en este caso se podría decir confrontación, al defender cada uno de estos Estados posicionamientos distintos, sobre todo con Obama en el poder, hoy en día más mitigados. Dicho esto, tampoco conviene olvidar que el EI ha sido objeto de imitación, e incluso de adulación, para otros muchos grupos terroristas presentes en Estados no vecinos, como Libia y Nigeria, así como en otros del Sahel como Mali.

Pero en el conflicto sirio también ha habido un cierto papel desempeñado por otros Estados de una forma más sigilosa. A este respecto, no conviene olvidar a Qatar, hoy en día acorralado por Arabia Saudí y otros países del Golfo. La hipocresía de este pequeño país, aunque influyente por sus arcas financieras, y que ha armado a los grupos rebeldes, sobre todo a aquellos más islamistas, al régimen sirio, no tiene parangón. Y es que, el 23 de octubre de 2012, el Emir de Qatar, Cheik Hamad ben Khalifa al-Thani, hizo unas declaraciones, que fueron recogidas rápidamente por el diario ginebrino Tribune de Genève en su redacción digital del mismo día 23 de octubre de 2012, en las que solicitaba en la Asamblea General de las Naciones Unidas una intervención militar en Siria por parte de los países árabes con el fin de poner fin a lo que el Secretario General de la ONU calificó de «desastre regional con implicaciones mundiales». Es más, incluso recordó el precedente de la intervención militar que llevó a cabo la Liga Árabe en 1976 en Líbano para poner fin a la

70 Véase, por ejemplo, el análisis de ECHEvERRía, C., «Evolución y perspectivas del conflicto de Siria: el factor islamista», Análisis del Grupo de Estudios Estratégicos, 28 de febrero de 2013 (http:// www.gees), pp. 1-4. 
cruenta guerra civil libanesa. Se da el caso de que en esa ocasión, unos 30.000 soldados, mayoritariamente sirios, se desplegaron en el Líbano en octubre de 1976 para evitar la continua sangría que estaba causando la terrible guerra civil libanesa.

No queremos terminar estos comentarios sin señalar el comportamiento ejemplar israelí durante toda la crisis siria, manteniéndose el país hebreo en una auténtica neutralidad, a pesar de que tiene mucho que decir tanto desde el punto de vista militar como político. Tan sólo ha realizado incursiones para destruir convoyes de armas y misiles destinados a Hezbolláh, cosa que ha hecho con gran destreza y sin muchas contemplaciones. $\mathrm{Y}$ es que se diga lo que se diga, Siria sería un pequeño desayuno militar para las fuerzas del Tsahal, aunque Israel, como es obvio, no se fía tampoco de los opositores, por mucho que algunos piensen que Israel se frotaría las manos si desaparece el régimen sirio, algo que han apuntado algunos analistas de nuestro país, y que no concuerda con las tesis israelíes. Las cosas en la zona no son tan fáciles como algunos las pintan, y mucho menos si para esa zona se utilizan los parámetros occidentales de forma ingenua. $\mathrm{Y}$ es que como ha ocurrido en Libia, la democracia no siempre se puede imponer a golpe de cañonazos en estos países, salvo que se adopten unas medidas que los mismos países que las propugnan no están dispuestos a adoptar, como en el caso libio. Si a esto añadimos que muchas potencias occidentales se acuerdan de los derechos humanos cuando están en juego sus intereses o creen que lo están, tenemos todos los ingredientes para ir enarbolando una hipocresía magistral, convirtiendo además a la «responsabilidad de proteger», en una especie de arma arrojadiza, en la que el remedio es peor que la enfermedad.

\subsection{La ausencia de la figura de la responsabilidad de proteger tanto en el caso sirio como en la lucha contra el EI}

Tanto en el caso sirio, aunque sobre todo en la lucha contra el EI, no deja de sorprender la imposibilidad de llegar a un acuerdo para articular una respuesta militar amparada en la responsabilidad de proteger. Sin embargo, es comprensible que si no fue posible en el caso del conflicto sirio ${ }^{71}$, también

71 Sobre esta cuestión, véase el análisis de GUTIÉRREZ ESPADA, C., «Choque de civilizaciones (el autoproclamado Estado Islámico...)», pp. 160 y ss. Igualmente, SAIRA, M., «The UN Security 
lo debía ser en el caso del EI, ya que desde mediados del 2011, varios miembros del entonces ISI (Estado Islámico de Irak) fueron enviados al Norte de Siria, contando además con el apoyo de grupos de Al-Qaeda, dirigidos por AlZawahiri. De esta colaboración surgiría el famoso Frente Al-Nusra, que iría incrementando sus efectivos tanto con miembros procedentes de Siria como de países extranjeros, mientras que los miembros del ISI daban prioridad a la lucha en Irak. Los intentos de este último de controlarlo o integrarlo en su organización no funcionaron, suscitándose una controversia entre ambos grupos que tuvo que resolver, como si de un arbitraje se tratara, Al-Zawahiri, que decidió en contra de la unificación en mayo de 2013. La toma de Faluya por las fuerzas del entonces ISIS (Estado Islámico de Irak y Levante) en los inicios de 2014, sería el inicio de una gran expansión que les llevaría a la toma de Mosul, huyendo los miembros del ejército iraquí, y dejando como ya se ha apuntado, una gran parte de su material militar ${ }^{72}$, incluido armamento pesado estadounidense.

Así las cosas, es evidente que en el conflicto sirio, bien sean las fuerzas del régimen, como los grupos rebeldes, han cometido graves violaciones de derechos humanos, por mucho que los países occidentales hayan hecho más hincapié en las violaciones cometidas por las fuerzas del régimen. Esto se debe a que pocos apostaban en un principio por la supervivencia del régimen, siguiendo así los pasos de lo que había ocurrido en Túnez y Libia, a la luz de la llamada «primavera árabe». Evidentemente la «primavera árabe» iba a tener su repercusión en Siria y, como en otros países árabes, el elemento islamista iba a estar desde el principio muy presente ${ }^{73}$. En efecto, como se

Council and the crisis in Syria», American Society of Internacional Law Insights, vol. 16, 11, 2012, 26 March 2012; ZIFCAK, S., «The responsibility to protect after Libya and Syria», Melbourne International Law fournal, 13, 2012, pp. 1-35. Véase también las reflexiones de diversos autores en EfIL Talk (http://www.ejiltalk.org): AKANDE, D., «The legality of military action in Syria: humnitarian intervention and responsibility to protect», European fournal of International Law Talk, 28 de agosto de 2013; STAHN, C., «Syria and the semantics of intervention, aggression and punishment», EfIL Talk, 19 de septiembre de 2013, y «Syria, Security resolution 2118, 2013 and peace versus justice: two steps forward, one step back», E7IL Talk, 3 de octubre de 2013; HONGIU KOH, H., «Syria and the law of humanitarian intervention (Part II: International Law and the way forward», EFIL Talk, 4 de octubre de 2013; ID: «Syria and the law of humanitarian intervention (Part III: a reply)», EFIL Talk, 12 de octubre de 2013.

72 Cfr. Pozo SERrano, P., «El uso de la fuerza contra el Estado Islámico en Irak y Siria...», op. cit., pp. 147-148.

73 Sobre estos precedentes históricos, cfr. RUIZ MigueL, C., «Rebelión en Siria: ¿en la encrucijada o hacia el precipicio?», Anuario Español de Derecho Internacional, 2011, pp. 243 y ss. 
sabe, al mismo tiempo que se desató el conflicto armado interno en Libia, en Siria se fue gestando un frente de oposición al régimen de Bachar Al-Assad que desde el principio fue reprimido con dureza. Dado el cariz que habían adoptado ya las primaveras árabes en Túnez y Libia, la mayoría de los analistas ya daban por hecho la caída del régimen sirio más pronto que tarde, y se especulaba ya con un paradisiaco exilio para Al-Assad y su familia. Esta opinión era tan generalizada que el que fuera el militar más condecorado de Israel, Jefe de Gobierno y el que comandara la Operación Plomo Fundido sobre Gaza en diciembre de 2008 y enero de 2009 como un gran Director de Orquesta, el famoso Ehud Barak, declaró públicamente en Israel que al régimen de Al-Assad le quedaban tres semanas. Todo el mundo tiene el derecho a equivocarse, también Ehud Barak, y como lo cortés no quita lo valiente, así lo ha reconocido.

Conviene apuntar, sin embargo, que los opositores al régimen sirio distaban mucho de ser uno meros reivindicadores de libertades, a pesar de que, como es sabido, Siria haya sido gobernada con mano de hierro durante décadas. Es cierto que el conflicto árabe-israelí había encubierto en parte esta realidad, pero no es menos cierto que, como en Libia, la dureza y la falta de libertades del régimen no habían supuesto graves problemas de conciencia en las potencias occidentales, e incluso cuando en muchos foros se decía que Israel era la única auténtica democracia del Oriente Medio, uno encontraba en general enfrente aquellos que ahora parece que apoyan a los grupos opositores o rebeldes.

Así las cosas, si nos centramos ahora en los efectos de la Guerra en Libia sobre el conflicto sirio, conviene subrayar que estos no se han hecho esperar. $\mathrm{Y}$ es que incluso antes ya de la muerte de Gadafi, Rusia y China ya vetaron el proyecto de resolución de condena al régimen sirio presentado por los países europeos y los Estados Unidos en el consejo de Seguridad el 5 de octubre de $2011^{74}$. Y ello pese a que el proyecto de resolución había incluido una serie de precauciones para impedir que pudiera interpretarse como un primer paso para una futura intervención militar. Así pues, las esperanzas que tenían tanto los Estados Unidos, como Francia y el Reino Unido de que Rusia optase por la abstención, como hicieron Brasil, India, Líbano y Sudáfrica, se desvanecieron.

74 Sobre estos aspectos, cfr. BLANC ALTEMIR, A., «La Comunidad internacional ante la llamada Primavera Árabe», en GuTiÉRrez ESPADA, C. y CERvell HorTAL, M.J., Nosotros y el Islam, Diego Marín, Murcia, 2012, pp. 80 y ss. 
¿Sacaron pues sus conclusiones Rusia y China de la lección libia? La respuesta a esta pregunta parece ser positiva, al margen de las diferencias estratégicas y políticas que existen entre un caso y otro.

En efecto, como se sabe, el conflicto en Siria fue de mal en peor ${ }^{75}$ y hay abundantes datos, tanto respecto a las fuerzas gubernamentales como de los opositores o rebeldes, de graves violaciones de derechos humanos. Desde esta perspectiva, conviene apuntar que ya el 3 de agosto de 2011, el Presidente del Consejo de Seguridad adoptó una Declaración ${ }^{76}$ en la que se insta a las autoridades sirias a respetar completamente los derechos humanos y a cumplir con las obligaciones que impone el Derecho internacional, al mismo tiempo que reafirma la soberanía, la independencia y la integridad territorial de Siria, así como que la actual crisis en Siria sólo puede resolverse a través de un proceso político que incluya las principales y legítimas aspiraciones de la población. Pide, además, como no podría ser de otra manera, que se alivie la situación humanitaria en las zonas más críticas dejando de recurrir al uso de la fuerza contra las ciudades de dichas zonas y que se permita el acceso de las agencias y trabajadores humanitarios. Sin embargo, sorprende, como señala la profesora Domestici-Met que no se aluda expresamente a la «responsabilidad de proteger» ${ }^{77} \mathrm{y}$ a nosotros también nos sorprende que la representante libanesa, Carolina Ziade, se alejara de las ideas expuestas por el Presidente del Consejo de Seguridad, señalando que dicha Declaración no ayudaba a resolver la ac-

75 Sobre el conflicto en Siria, cfr. RUIZ MigueL, C., «Rebelión en Siria: ¿en la encrucijada o hacia el precipio», op. cit., pp. 243-268. Respecto a la posición de la UE y del Gobierno español en este conflicto, el autor señala lo siguiente: «La posición de la UE, a mi juicio, es una posición irreflexiva. En primer lugar, llama la atención, a mi juicio, que se hayan adoptado una serie de sanciones, graves, contra el gobierno sirio sin que previamente se haya enviado una misión de investigación sobre los hechos para determinar todas las responsabilidades existentes en relación con el uso injustificado de la violencia. Además, en segundo lugar, y relacionado con lo anterior, es notorio que las decisiones de la UE no se dirigen contra los sujetos o gobiernos que facilitan armas a los rebeldes o contra los rebeldes que usan la violencia. Ello transmite un mensaje, a mi juicio, muy peligroso que no es otro que el de avalar el uso de la violencia por los rebeldes islamistas. Por lo demás, la posición de la UE, y la del Gobierno español, no incide, en ningún momento, en la necesidad de respetar los derechos de las minorías en el país, algo que contrasta con la política de España, y de Francia, en la zona, en el pasado».

76 Cfr. Doc. S/PRST/2011/1C.

77 De esta autora, cfr. «Protecting in Libya on Behalf of the international Community», Göttingen Fournal of International Law, 2001, $\mathrm{n}^{\circ}$ 3, pp. 861-889. Sobre la Guerra en Libia y la responsabilidad de proteger, ver los trabajos publicados en el Anuario Español de Derecho Internacional, 2011, de Bermejo García, Gutiérrez Espada, Cervell Hortal y López-Jacoiste Díaz, pp. 9-152. 
tual situación en Siria ${ }^{78}$. Así las cosas, no se entiende que el Líbano jugara un papel activo en el caso libio y ahora quiera esconderse en el caso sirio, a no ser que esté practicando ante la comunidad internacional esa actitud tantas veces mencionada y condenada del doble rasero, aunque en este caso agravada dada la contemporaneidad de ambos conflictos.

Dos semanas más tarde de la Declaración del Presidente del Consejo de Seguridad, concretamente el 18 de agosto de 2011, la Alta Comisionada de las Naciones Unidas para los Derechos Humanos, Navy Pillay mencionó la responsabilidad de proteger en relación con el caso sirio, recordando que si un Estado no protege a su población de los crímenes internaciones que se están cometiendo, la comunidad internacional «bas the responsibility to step in by taking protective action in a collective, timely and decisive manner» ${ }^{79}$. Desde entonces, la citada Alta Comisionada se ha referido al caso sirio recordando, directa o indirectamente, la responsabilidad de proteger en numerosas ocasiones.

Dicho esto, lo que conviene poner de relieve también es que la Liga Árabe, que mantuvo un clamoroso silencio mientras se ocupaba de Libia, al hilo de los acontecimientos, y presionada por los países occidentales, empezó a adoptar varias iniciativas para encontrar una salida política a la crisis, aunque sin definir y precisar unos resultados concretos. Su tardía activismo en esta crisis se debe a varios factores, todos ellos importantes e interrelacionados, aunque el más esencial, el de los derechos humanos, sea quizás el que menos le interese, como apunta al respecto Salam KAWAKIVI en los siguientes términos:

«Su sorprendente activismo se debe probablemente a una combinación de factores: el tema a que el eco de los acontecimientos alcance a los regímenes de los países miembros; el afán por vigilar los acontecimientos para evitar el indeseable descontrol; la reacción personalizada frente al comportamiento oficial sirio, juzgado de irrespetuoso ante los influyentes líderes de la región, y el subsiguiente deseo de ajustar cuentas; la desestabilización

78 Cfr. Doc. SC/10352, de 3 de agosto de 2011, en donde se afirma: «Following the reading of that statement, Carolina Ziade of Lebanon disassociated her country from it, saying the text did not help to address the current situation in Syria. She stressed the interconnectedness of the two countries and said that the Lebanese people stood in support of the sovereignty and territorial integrity of Syria and the unity and safety of its people. She expressed regret over the loss of life and gave condolences to victims, and she hoped that reforms announced by the Syrian authorities would lead to progress and prosperity.

79 Cfr. «Report of the United Nations High Commissioner for Human Rights on the situation of human rights in the Syrian Arab Republic», IV, Recommendations, párrafo 92. 
regional; el temor a las agitaciones sociales y, por fin, el anhelo disimulado por encontrar una salida que permita al régimen acometer reformas parciales manteniendo el poder o una parte importante del mismo.

¿Y los derechos humanos? ¿Y las vidas inocentes? Es poco probable que dichas cuestiones hayan sido evocadas con seriedad por este organismo» ${ }^{80}$

Pero al margen de estas consideraciones que acabamos de apuntar, lo cierto es que a partir de noviembre de $2011^{81}$, y después de una mediación para aplicar un plan de paz, que Siria no aplicaría, lo cierto es que la Liga Árabe suspende a Siria de la Organización el 12 de noviembre de 2011, como hizo exactamente con Libia el 3 de marzo, mientras que el 27 de noviembre adoptaba sanciones ${ }^{82}$, amenazando al mismo tiempo con llevar el asunto sirio a las Naciones Unidas.

Desde entonces, la crisis siria ha seguido su camino sin que nada ni nadie haya podido poner coto al agravamiento de la situación. Y es que la creación del Consejo Nacional Sirio, puesto en marcha en octubre de 2011, aunque su creación fue anunciada en Estambul el 23 de agosto de 2011, no ha facilitado las cosas, negándose sistemáticamente a aceptar cualquier propuesta de creación de un Gobierno de unidad o de un Gobierno transitorio con los dirigentes del régimen sirio, ya que piden que su Presidente Al Assad deje el poder, idea a la que se sumaron, de forma sistemática, también dirigentes occidentales, liderados por Hillary Clinton, entre ellos nuestro Ministro de Asuntos Exteriores García Margallo ${ }^{83}$. Por otro lado, el plan de Kofi Annan, Enviado Especial a la zona, también fracasó y no dudó en culpar a la Comunidad internacional de la situación en Siria ${ }^{84}$.

A este respecto, todas las propuestas y proyectos de resolución que se han barajado han encontrado en Rusia y China una oposición contundente,

80 De este autor, cfr. «Siria: una crisis sin fin ni respuesta internacional», Política Exterior (Mayo/ Junio 2012), p. 78.

81 Gadafi muere el 20 de octubre.

82 A este respecto, cfr. Arab League Res. 7442, de 27 de noviembre, en http://www.openbriefing. org/regionaldesks/middleeast/resolution7442/

83 La salida del poder del Presidente sirio fue recordada el 6 de julio de 2012 en París durante la tercera reunión de los países Amigos de Siria, que son cerca de un centenar. En esta ocasión, el Presidente francés dijo que «la caída de El Asad es ineluctable», y que «debe marcharse porque eso es lo que quiere su pueblo». Por su parte, Hillary Clinton dijo de China y Rusia que «están bloqueando los progresos. Esto ya no es tolerable». Y es que estos dos países pedían que se formara un Gobierno de transición que incluyera a dirigentes del actual régimen y de la oposición. Cfr. http://internacional.elpais.com/internacional/2012/07/06/actualidad/1241564162_664 (06/07/2012).

84 Cfr. http://www.larazon.es/noticia/581-annan-responsabiliza-a-la-comunidad-internacional $(30 / 06 / 2012)$ 
señalando que no van a tolerar en Siria lo que se hizo en Libia. Para estos dos países, la crisis siria sólo puede resolverse sin ninguna injerencia exterior y mediante el diálogo político ${ }^{85}$. Desde esta perspectiva, descartada la posibilidad de llevar a cabo una intervención militar en Siria al amparo de la responsabilidad de proteger tras el desastroso ejemplo que los países miembros de la OTAN, acompañados de algunos acólitos medioorientales como Qatar, protagonizaron en Libia, la comunidad internacional se dirigía por sendas peligrosas y sin rumbo, permitiendo así que el conflicto se encastrara en una lucha a muerte entre las fuerzas del régimen y el conglomerado de grupos rebeldes cada uno de ellos de distinta índole y condición, situación que aprovecharía el EI para adentrase también en el conflicto, cometiendo las atrocidades de todos conocidas, aunque hoy en día se encuentre en la cuerda floja.

\subsection{La lucha contra el EI a solicitud de Irak y la coalición internacional}

La imposibilidad de llevar a cabo una respuesta militar contundente e institucionalizada por las razones antes apuntadas, la lucha contra el EI se iba a llevar a cabo no solo de una forma descentralizada, sino incluso de una forma un poco caótica, ya que los intereses de los Estados intervinientes iban a estar presentes en muchos casos por encima de una derrota inmediata del $\mathrm{EI}^{86}$. Esto hay que tenerlo siempre presente, ya que sino no se entiende en absoluto que ante el empuje que en los años 2013/14 iba adquiriendo el EI, muchos Estados que tenían una gran responsabilidad en el caos iraquí y en cómo se iba desarrollando el EI, no hicieran nada para evitarlo. Así las cosas, y viendo el peligro in situ que representaba el EI, el Primer Ministro iraquí, Al Mulik, chií, solicita asistencia militar a varios países, entre ellos a los Estados Unidos, antes de que cayera en manos del EI la importante ciudad de Mosul, que tuvo lugar ya el 8 de junio de 2015.

La solicitud del Gobierno iraquí se hace en realidad mediante una carta fechada el 25 de junio de 2014, por lo tanto ya tras la caída de Mosul, y enviada desde la Representación Permanente de Irak ante las Naciones Unidas ${ }^{87}$. Por

85 Este es un aspecto que subrayaba también el Enviado Especial Kofi Annan, cuando dice: «Este es un problema sirio, con orígenes sirios y la principal responsabilidad para resolverlo recae en los sirios. Pero la comunidad internacional, particularmente las potencias en esta sala, tiene un papel de apoyo esencial. Unidos podéis ayudar a crear las condiciones que permitirían a los sirios a crear su propia solución política. Pero si estáis divididos, las posibilidades de este resultado disminuyen»: Ibid.

86 Para más detalles, cfr. Fronson, J y SIMON, S., «ISIS: The Dubiouns Paradise of Apocalipse Now», Survival, p. 7-56.

87 Cfr. Doc. S/2014/440, de 25 de junio de 2014. 
lo tanto es una solicitud que se hace a la comunidad internacional ${ }^{88}$, aunque el Gobierno iraquí también lo hizo antes con algunos países, petición que fue cursada ya el 8 de Junio de 2014, es decir, antes de la caída de Mosul, al ver que las tropas iraquíes se retiraban en desbandada y no hacían frente a las fuerzas combatientes del EI. En este último caso, Irak se basaba en ciertos acuerdos bilaterales. A este respecto, la Profesora Pilar Pozo Serrano menciona dos tratados adoptados el 17 de noviembre de $2008^{89}$, pero que los Estados Unidos fueron reticentes a aplicarlos a pesar de que el Primer Ministro Al Maliki había solicitado a los Estados Unidos a llevar a cabo bombardeos aéreos o de otra índole contra los objetivos del EI en territorio iraquí, demanda que en esos momentos los Estados Unidos no cumplieron, aunque enviaron fuerzas con funciones de inteligencia, de entrenamiento de las fuerzas iraquíes y kurdas, excluyendo expresamente la participación de esas fuerzas en los combates, pero proporcionando armamento y munición. Esta solicitud iraquí puso en realidad a la Administración de Obama en un grave apuro, ya que había sido él el que había decidido retirar sin más todas las tropas estadounidenses de Irak. Y es que, si esto no hubiera tenido lugar, otro gallo hubiera cantado para el EI en Irak ${ }^{90}$. La responsabilidad de Obama frente a la situación que se estaba produciendo en Irak era obvia, por mucho que el rechazo a llevar a

88 Para más detalles, cfr. BANNELIER-CHRISTAKIS, K., «Military Interventions against ISIL in Irak, Syria and Lybia, and the Legal Basis of Consent», Leiden fournal of International Law, 2016, pp. 250 y ss. Para un estudio en general sobre los efectos del consentimiento a una intervención militar, cfr. DOSWALD-BECK, L., «The Legal Validity of Military Intervention by Invitation of the Government», British Yearbook of International Law, 1986, pp. 189-252 y ss.; igualmente CHRISTAKIS, T. y BANNELIER, K., «Volenti non fit injuria?. Les effets du consentiment à l'intervention militaire», Annuaire français de droit internationsl, 2004, pp. 102-137; y para el caso de Mali, de estos mismos autores, véase «Under the UN Security Council's Watchful Eyes: Military Intervention by Invitation in the Malian Conflict», Leiden Fournal of International Law, 2013, pp. 855-874.

89 De esta autora, cfr. «El uso de la fuerza contra Estado Islámico en Irak y Siria...», op. cit., p. 150, nota 26.

90 Este es un aspecto en el que no se suele incidir, pero que es sumamente relevante, como lo explica Gabriel Albiac al decir lo siguiente: «En enero de 2009 George Bush cerraba su mandato. La presencia militar garantizaba la pacificación del territorio iraquí. No eran necesarias virtudes proféticas para saber lo que sucedería si esas tropas eran retiradas. Estallaría una guerra que se extendería a todos los territorios colindantes. Fue lo que hizo Barak Obama, responsable último de lo que vino luego. Daesh se instaló en la zona abandonada por los americanos. Había aprendido de la derrota de Bin Laden...». Cfr. ABLIAC, G., «Glacial», $A B C$, de 28 de agosto de 2017. Y es que el Presidente Obama, retirando las tropas de Irak en enero de 2009 y con su discurso de El Cairo de mayo del mismo año, es evidente que incendió el mundo árabe y desató los conflictos que todos conocemos, algunos de los cuales se analizan en este trabajo. 
cabo los ataques contra el EI lo justificara recurriendo a argumentos democráticos, señalando que solo un Gobierno representativo de Irak, lo que no era el Gobierno de Al Maliki, sería capaz de hacer frente a la situación. Es decir, los Estados Unidos querían mostrar que el Gobierno iraquí de aquel entonces era en buena parte responsable de la situación, generada por sus políticas sectarias contra las minorías, y sobre todo contra los suníes.

No obstante, como la situación se volvía cada vez más grave, una coalición liderada por los Estados Unidos llevó a cabo ya el 8 de agosto de 2014 una serie de ataques aéreos en el marco de la Operación Inherent Resolve $e^{91}$, dejando claro el Presidente Obama que tales ataques se llevaban a cabo a invitación del Gobierno iraquí para ayudar a las fuerzas iraquíes a combatir una organización terrorista que usa bárbaros métodos de combate ${ }^{92}$. Y es que el Presidente Obama, consciente de la situación que en esos momentos padecía la población yazidí en las montañas de Sijar, donde se había refugiado, quería prestarles el apoyo humanitario necesario y liberarlos del asedio al que estaban sometidos por el EI con serios riesgos de genocidio ${ }^{93}$. En una situación similar se encontraban otras minorías cristianas en la zona, tal y como anunciaban muchas agencias de prensa de la zona, sobre todo las israelíes, así como el Vaticano y algunas ONG's. En esta Operación, con los Estados Unidos participaron también Australia, Bélgica, Canadá, Dinamarca, Francia, Jordania, los Países Bajos y el Reino Unido, mientras que otros países se unieron a esta coalición proporcionando apoyo logístico.

En estos ataques, como se puede ver, no mencionamos a Turquía, país que proporcionó ciertas facilidades para llevar a cabo algunas operaciones, pero sin participar en ningún ataque. Más tarde se anunció por el portavoz de esta Coalición, que Turquía no formaba parte de ella ${ }^{94}$. La razón es que el Gobierno iraquí había protestado en repetidas ocasiones contra incursiones llevadas a cabo en territorio iraquí en su lucha contra los kurdos. Una de las

91 Cfr. Operation Inherent Resolve: Targeted Operations Against ISIL Terrorists, US Department of Defense, available at www.defense.gov/New/Special-Reports/o814_Inherent-Resolve.

92 Statement by the President, The White House, 7 august 2014, en at www.whitehouse.gov/thepress-office/2014/08/07/statement-president.

93 Sobre los yazidíes y las atrocidades que han padecido, véase el artículo recién publicado en El País digital (29 de agosto de 2017) de Pablo Cobos, con el título «El sufrimiento del pueblo más odiado del pueblo islámico». Es el clásico caso de intervención humanitaria o de responsabilidad de proteger en el que no se actuó a tiempo, mirando hacia otro lado.

94 Cfr. Turkey Not Part of US-Led Coalition in Iraq - Coalition Spokesman, Sputnik International, 2 february 2016, en sputniknews.com/middleeast/20160202/1034091107/turkey-us-led-coalition-iraq.html\#ixzz3zUitAmx1. 
más importantes se llevó a cabo en febrero de 2008, en la que el Presidente Erdogán expresamente declaró que se llevaba a cabo al amparo de la legítima defensa ${ }^{95}$. Pero posteriormente, Turquía seguiría con esas operaciones, llevando a cabo además una importante en diciembre de 2015, en la que cientos de soldados turcos llegaron cerca de Mosul, es decir unos $110 \mathrm{~km}$ dentro del territorio iraquí.

Esta operación suscitó una respuesta contundente por parte del Representante Permanente de Irak ante las Naciones Unidas, quien en una carta fechada el 14 de diciembre de $2015^{96}$, al Presidente del Consejo de Seguridad señalaba que las acciones armadas turcas se habían llevado a cabo sin previa coordinación o consulta con el Gobierno federal de Irak y que por lo tanto constituían una flagrante violación de las disposiciones y principios de la Carta de las Naciones Unidas, violando además la integridad territorial y la soberanía del Estado iraquí. Para Irak, esas operaciones constituían por lo tanto una agresión según la Carta de las Naciones Unidas y según las disposiciones más relevantes del Derecho internacional en la materia. Turquía intentó rebajar la tensión, señalando que era una operación de rutina con el fin de proteger a las tropas que entrenaban a los grupos que luchaban contra el EI, aunque reconociendo que había habido una falta de comunicación con el Gobierno iraquí, reiterando al mismo tiempo el respeto de la soberanía y la integridad de Irak. Unos días más tarde el propio Presidente Obama instó a Erdogán a retirar las tropas de Irak de una forma amenazante ${ }^{97}$.

Conviene poner de relieve, sin embargo, que esta Operación tuvo también otros objetivos que cuadran con ciertos intereses estadounidenses como la protección del personal e instalaciones estadounidenses en Erbil, capital del Kurdistán iraquí, región que goza de una gran autonomía y muy vinculada a la parte protegida por los Estados Unidos desde la guerra de Irak de 2003, en la que los Peshmergas Kurdos, excelentes combatientes, prestaron una gran ayuda a las fuerzas estadounidenses ayudándoles a abrir el frente norte ante el rechazo de Turquía a dejar pasar las tropas estadounidenses por su territorio ${ }^{98}$.

\footnotetext{
Sobre esta cuestión, cfr. infra.

Cfr. Doc. S. 2015/963.

97 «Obama to Erdogan: Withdraw Turquish Troops from Irak», Pres IV, 19 de diciembre de 2015, en 217.218.67.231/Detail/2015/12/19/442304/US-Turkey-Obama-Erdogan-Turkish-troops-Iraq.

98 La combatividad de los Peshmergas Kurdos se ha demostrado una vez más en la lucha contra el EI, ya que en 2014, mientras las tropas iraquíes daban la espantada, estos luchaban encarnizadamente y resistían. Es más, el EI ha encontrado un enemigo feroz en los Peshmergas Kurdos, y gracias a ellos, el territorio ocupado por el EI se redujo considerablemente.
} 
En este estado de cosas, por cierto bastante confuso y convulso, tiene lugar un acontecimiento propiamente interno iraquí, pero muy importante, como fue la configuración de un nuevo gobierno en Irak, con Al Abadi al frente como Primer Ministro, el 11 de agosto de 2014, lo que ayudó, vistas las malas relaciones del Presidente Obama con Al Maliki, a que el primero de estos anunciara el 10 de septiembre su decisión de formar una gran coalición internacional con el fin de debilitar al EI primero, y destruirlo después, recurriendo a una estrategia de ataques de forma ininterrumpida ${ }^{99}$. Con este mar de fondo, se abre unos días después, concretamente el 15 de septiembre, una Conferencia sobre la Paz y Seguridad en Irak, a iniciativa de los Presidentes de Francia e Irak, a la que asistieron 26 Estados, entre los que se encontraban los cinco Miembros Permanentes del Consejo de Seguridad, más nueve Estados árabes, además de Turquía. Estaban también presentes los representantes de tres Organizaciones internacionales: las Naciones Unidas, la Liga Árabe y la Unión Europea.

Los participantes en la Conferencia mostraron su satisfacción por la formación del nuevo Gobierno en Irak, y además declararon de forma contundente que el EI representaba una amenaza no solo para Irak sino para la comunidad internacional en su conjunto ${ }^{100}$. Pero, además, y en nuestra opinión es lo más importante, todos los participantes reconocen la necesidad urgente de poner fin a la presencia del EI en las regiones en las que ha tomado posiciones en Irak. Con este fin se comprometen a apoyar, con los medios necesarios, al nuevo Gobierno iraquí en su lucha contra el EI, incluso con una ayuda militar apropiada. Estas ideas, como se puede ver con fines además muy específicos, se recogen en las Conclusiones de la Conferencia ${ }^{101}$, aunque quizás lo más im-

99 Cfr. The White House, Statement by the Presiden ton ISIL, 10 de septiembre, 2014, en www. whitehouse.gov/the-press-office/2014/09/10/statemjent-president-isil-1.

100 Desde entonces, la idea de que el EI era «una amenaza para la comunidad internacional en su conjunto» iba a estar presente en numerosos foros con términos similares, o incluso más graves como los que figuran en el preámbulo de la Resolución 2249, de 20 de noviembre de 2015, en donde se recoge la expresión de que el EI es «una amenaza mundial sin precedentes». Sobre esta Resolución y su alcance, cfr. infra.

${ }^{101}$ Cfr. www.diplomatie.gouv.fr/es/fichas-de-paises/irak/eventos/article/conclusiones-de-la-conferencia. Sobre esta coalición internacional véase el estudio de WECKEL, Ph., «Lutte contre Daech (EI), una nouvelle coalition militaire?» Bulletin Sentinelles, $\mathrm{n}^{\circ}$ 403, 21 septiembre 2014, pp. 1-11, en donde se recogen también las Conclusiones de la Conferencia. Entre nosotros, ver también GUTIÉRREZ ESPADA, C., «Choque de civilizaciones» (el autoproclamado Estado Islámico...», op. cit., pp. 122 y ss.; y POZO SERRANO, P., «El uso de la fuerza contra el Estado Islámico...», op. cit., pp. 152-153. 
portante sea que todos se comprometen a apoyar, «con los medios necesarios» al nuevo Gobierno iraquí en su lucha contra el EI.

Dicho esto, no conviene perder de vista que de todos los Estados presentes en la Coalición tan sólo los Estados Unidos y Francia contaban con los medios apropiados para llevar a cabo bombardeos aéreos sobre las posiciones del EI, y cada uno de ellos lo hizo de forma independiente, es decir, sin estar integrados militarmente para llevar a cabo esas operaciones. Por eso, Philippe Weckel ${ }^{102}$, ya señala, en nuestra opinión con razón que hubiera sido conveniente un mando militar único que debería haber correspondido a los Estados Unidos. Por otro lado, no sirve de mucho crear una gran coalición si la mayoría de Estados colaboran o participan de una forma meramente simbólica. No obstante, la Coalición se fue ampliando y a principios de 2016 ya contaba con 64 Estados de toda índole y condición, entre los que se encontraban Kosovo y Taiwán ${ }^{103}$. Y es que una buena parte de ellos se han dedicado a impedir el reclutamiento de combatientes extranjeros por el EI, luchar contra la financiación del Estado Islámico, prestar ayuda humanitaria, y difundir la verdadera naturaleza del EI ${ }^{104}$.

Pero si los países de la Coalición habían recibido el consentimiento expreso del Gobierno iraquí, e incluso más, fueron instados por el propio Gobierno iraquí a que intervinieran contra el EI, este no es el caso de Siria y, sin embargo, los países de la Coalición también llevaron ataques en Siria, planteándose así la cuestión de la legalidad de dichas intervenciones. Los ataques se iniciaron ya el 22 de septiembre de 2014, justo unos días después del discurso del Presidente Obama en el que hacía alusión a que su intención no solo era degradar al EI, sino al final destruirlo mediante una estrategia creíble y sostenida en materia antiterrorista, así como abatir (hunt down) los terroristas que amenacen los Estados Unidos allí donde se encuentren (wherever they

102 Cfr. «Lutte contre Daech (EI)...», op. cit.

103 Por estas fechas ya se habían llevado a cabo 6763 ataques aéreos por parte de la Coalición en Irak, sin embargo lo que está claro es que al no disponer de tropas de combate sobre el terreno, sus efectos se relativizaban considerablemente. Esta cuestión se puso en muchas ocasiones de manifiesto, incluso por mandos militares estadounidenses, aunque como se sabe, el Presidente Obama no las tomó en consideración, no se sabe si por orgullo, o por convicción, aunque en nuestra opinión sería más lo primero. Se ha tenido que esperar, pues, a que los Kurdos, que habían bien resistido los envites del EI, y que las fuerzas iraquíes, tras la espantada inicial, se rehicieran, para que la iniciativa militar estuviera en sus manos, consiguiendo así el repliegue casi general de las fuerzas del EI como lo demuestra la batalla, y a la postre, la caída de Mosul.

104 Cfr. GUTiÉrrez EsPadA, C., «Choque de civilizaciones (el autoproclamado Estado Islámico)...», op. cit., p. 125. 
are $)^{105}$. Desde entonces, varios miles de ataques aéreos se han llevado a cabo sobre Siria, y algunos de ellos han sido relevantes ${ }^{106}$.

En realidad, la cuestión de la intervención en Siria se planteó ya en la Conferencia de París, oponiéndose Rusia con el argumento de que no había autorización del Consejo de Seguridad. Esta autorización o invitación por parte del Gobierno sirio nunca se produjo, por lo que al contrario de Rusia e Irán, es imposible justificar las operaciones militares llevadas a cabo por la Coalición sobre esas bases. Habría que recurrir con mucho optimismo a la teoría del «consentimiento pasivo» ${ }^{107}$ que no solo es muy controvertida, sino que además sería imposible de aplicar en el caso sirio a la luz de los hechos tal y como se han venido produciendo.

\subsection{La lucha contra el EI al amparo de la legítima defensa}

Desde los primeros instantes en los que se tuvo conocimiento de los ataques llevados a cabo en territorio iraquí, se vuelve a plantear a nivel internacional tanto por los Estados como por la doctrina internacionalista el tema siempre presente de la legítima defensa, aunque aquí se tratara de un actor «no estatal». Sin embargo, los amplios territorios que poco a poco fue ocupando el EI primero en Irak y luego en Siria, a lo que conviene añadir un número importante de combatientes bien armados con ánimo de crear el famoso Califato dejó ver claramente que se trataba de un conflicto contra un actor no estatal de características muy especiales, al contar tanto directa pero sobre todo indirectamente

${ }^{105}$ Cfr. Statement by the Presiden ton ISIL, The Whige House, 10 september 2014, en www. whitehouse.gov/the-press-office/2014/09/10/statement-president-isil-1.

106 A este respecto, cfr. BANNELIER CHRISTAKIS, K., «Military Interventions against ISIL in Irak, Siria and Libya...», op. cit., p. 766. Hasta primeros de febrero de 2016 los países que llevaron estos ataques en Siria fueron Arabia Saudí, Australia, Bahrein, Canadá, Emiratos Árabes Unidos, Francia, Jordania, Turquía y el Reino Unido. De estos países hay que resaltar Arabia Saudí que en 2013, tras haber sido elegida para ocupar un puesto de Miembro permanente del Consejo de Seguridad renunció a él al día siguiente invocando la incapacidad de este importante órgano onusiano para asumir sus responsabilidades para con la paz mundial. En sí, esta actitud lo que revelaba era su descontento no solo ya con el Consejo de Seguridad, sino con los Estados Unidos por no involucrarse más en el conflicto sirio. El puesto de Arabia Saudí fue ocupado después por Jordania.

107 Esta figura trae a colación aspectos como el silencio, la inacción, la ausencia de protesta, la pasividad e incluso la aquiescencia, que pueden desempeñar un papel relativamente importante según el adagio latino qui tacit consentire videtur si loqui debuisset ac potuisset, que hay que combinar con la otra que es volenti non fit injuria, lo que no deja mucho margen de maniobra. 
con el apoyo de algunos Estados de la zona. Solo así se puede explicar su rápido desarrollo como grupo armado, sus victorias frente al ejército iraquí, que se suponía bien armado y bien entrenado, y sus amplias conquistas territoriales, tanto en Irak como en Siria. En esta situación, es obvio que Estados como Irak no solo consintieran en que Estados terceros pudieran intervenir militarmente en la zona y venir en su ayuda, como ya hemos descrito anteriormente, sino que se trataba de saber, una vez más, si se podía invocar la legítima defensa frente a estos grupos armados no estatales. Si a esto añadimos los ataques terroristas cometidos en ciertos países europeos, y reivindicados por el EI, frente a los cuales se invocó la legítima defensa de forma contundente ${ }^{108}$, parece claro que las nuevas tendencias de las que aquí se ha hablado salen claramente reforzadas.

La invocación de la legítima defensa contra el EI ha vuelto a suscitar un debate doctrinal importante ${ }^{109}$, en donde se atisba que se incrementan las tesis defendidas en favor de que en casos de esta índole se reconozca el derecho de legítima defensa, tesis que se refuerza también con la práctica estatal reciente. No obstante, otros siguen manteniendo las tesis clásicas y defendiendo que la forma más adecuada jurídicamente hablando es el previsto por la Carta de las Naciones Unidas en materia de seguridad colectiva. Desde esta perspectiva, hay que reconocer que con el EI se vuelven a plantear en materia de legítima defensa las mismas cuestiones que tras el 11-S, que ya hemos analizado, aunque ahora de una forma más aguda a causa de esas nuevas tendencias que venimos comentando, y que se constatan fácilmente. A este respecto, lo primero que hay que destacar es que el artículo 51 de la Carta de las Naciones Unidas recoge una regla que ya existía anteriormente, como bien señala la Corte Internacional de Justicia en el ya citado Asunto de Nicaragua ${ }^{110}$, rebatiendo así las tesis de algunos

\footnotetext{
108 A pesar de que el recurso a esta cláusula no ha sido del gusto de todos, pues algunos hubieran preferido invocar otros mecanismos, como el artículo 222 del Tratado de Funcionamiento de la Unión Europea, lo cierto es que Francia, país que lidera una defensa europea autónoma y propia, la invocó. Sobre estos aspectos, cfr. por ejemplo, GOUTTEFARDE, F., «L'invocation de l'article 42.7 TUE ou la solidarité militaire européenne à l'épreuve de la guerra contre le terrorismo», Revue générale de droit internationel public, 2016, pp. 51-68.

109 Aparte de los ya citados en este trabajo, y sin ánimo de exhaustividad hay que mencionar los publicados fuera de nuestras fronteras en la revista Leiden fournal of International Law, 2016-29 y 2017-30, así como en la Revue générale de droit international public, de 2016-1 y Revue belge de droit international, de 2016-1. En esta última revista, figura en varios idiomas un manifiesto firmado por unos 300 juristas con el título «Contra una invocación abusiva del derecho de legítima defensa para hacer frente al terrorismo», y que de forma general no compartimos del todo, aunque sí se pueden defender algunos de sus planteamientos.

${ }^{110}$ Cfr. CIf Recueil, 1986, párrafo 186.
} 
autores ${ }^{111}$. Y lo segundo es que la legítima defensa constituye la principal excepción o limitación a la regla de la prohibición del uso de la fuerza, ya que, como señala el Profesor Serge Sur, si imagináramos un sistema jurídico internacional organizado que dispusiera de una fuerza pública para garantizar la regla general de la prohibición del uso de la fuerza armada por los Estados, la legítima defensa subsistiría, pues el artículo 51 dispone en su tenor literal que es inherente a los Estados. Es más, cuando indica que «Ninguna disposición de esta Carta menoscabará el derecho inmanente de legítima defensa» (droit natural, en francés) deja claro que ninguna, incluyendo el famoso artículo 103 de la Carta que consagra el principio de la primacía de la Carta sobre otras obligaciones de cualquier convenio internacional ${ }^{112}$. Por lo tanto, este carácter de «inmanencia» solo se recoge para la legítima defensa, como ya señaló Roberto Ago en su adición al octavo Informe sobre la responsabilidad de los Estados ${ }^{113}$.

$\mathrm{Si}$ decimos esto es porque aquellos que niegan el derecho de legítima defensa a los Estados que son atacados por estos actores no estatales, denominados también grupos privados, grupos armados, etc., siguiendo así las directrices de lo que se ha denominado la doctrina clásica, sobre todo en materia de atribución, minimizan el alcance de este derecho que es esencial para el propio mantenimiento de la paz y seguridad internacionales, y para la supervivencia de los Estados ${ }^{114}$. Y es que no siempre es factible poder atribuir los ataques de estos grupos armados al Estado, tal y como se ha interpretado el artículo 3 (g) de la Resolución 3314 sobre la agresión ${ }^{115}$, y no por ese simple hecho hay que dejar al Estado atacado sin derecho a defenderse. Pero es que, además, como ya hemos apuntado, el artículo 51 de la Carta no dice que el ataque debe proceder obligatoriamente de un Estado. Esto no quiere decir que no se tenga que reconocer que tanto en el caso del artículo 51, como en el de otros tratados, en el que se prevé una cláusula defensiva, como el artículo 5 de la OTAN, no se estuviera pensando en que el ataque procedería de un Estado ${ }^{116}$.

111 Ver, por ejemplo, ALLAND, D., «La legitime défense et les contremesures dans la codification du droit international de la responsabilité», Fournal du droit international, 1983, p. 738.

112 Cfr. SUR, S., «L'inhérence en droit international», Revue générale de droit international public, 2014, p. 787.

113 Cfr. Anuario de la Comisión de Derecho Internacional, 1980, vol. II, primera parte, p. 70.

114 A este respecto, cfr. supra.

115 Sobre la agresión indirecta y los debates que se suscitaron a la hora de su adopción, cfr. BERMEJO GARCÍA, R., El marco jurídico internacional..., op. cit., pp. 259-264.

116 A esto hace referencia precisamente el Juez Kooijmans en su opinión separada en el Asunto de las Actividades Armadas en el Congo de 2005, en Recueil, p. 314, párrafo 28. Conviene apunar a 
Sin embargo, ya se sabe que la OTAN lo invocó en el caso de los atentados del 11-S, atentados atribuidos a Al-Qaeda, y Francia ha recurrido al artículo 42.7 del Tratado de la Unión Europea tras los atentados cometidos en su territorio en el año 2015, atribuidos al EI. Y es que en estos casos no se discutió realmente si el autor del ataque que genera la legítima defensa debía ser un Estado o no, salvo en el caso del Tratado de la UE, en donde ese aspecto sobrevoló y, en nuestra opinión, estuvo presente en la mente de los negociadores, que plasmaron en el fracasado Tratado Constitucional la cláusula de defensa mutua, e incluso en el Documento Solana de 2003, sobre todo en materia antiterrorista.

Hechos estos comentarios, conviene recalcar que a pesar de que el tenor literal del artículo 51 de la Carta no dice que debe ser un Estado, parte de la doctrina sigue defendiendo las tesis clásicas, es decir que el ataque debe proceder de un Estado o atribuido a él, según los criterios expuestos por la Corte Internacional de Justicia, en el Asunto de Nicaragua, y en otros asuntos posteriores ${ }^{117}$. Así, por ejemplo, la Corte Internacional de Justicia señaló en la Opinión sobre el Muro (de Israel) de forma clara que el artículo 51 reconoce la existencia de un derecho inmanente de legítima defensa en caso de ataque armado por parte de un Estado contra otro Estado ${ }^{118}$. Y es que la Corte declaró ilegal el Muro, porque se ha construido sobre territorio palestino, negando a Israel el derecho a invocar la legítima defensa frente a los ataques terroristas u otras clases de ataques provenientes de los territorios ocupados, adoptando así una senda completamente contraria a la que adoptó la Corte Suprema israelí el 1 de julio de 2004. La base jurídica sobre la que se apoya la Corte es la tesis defendida por el Profesor Abi-Saab según la cual para poder invocar la legítima defensa es necesario que el ataque proceda de un Estado, bien sea directa o indirectamente, algo que no encontramos en los territorios palestinos, ya que estos están ocupados. Esta Opinión de la Corte no fue seguida, como se sabe, por los jueces Higgins, Kooijmans y Burgenthal, para quienes un ataque armado que dé lugar a la legítima defensa, puede proceder de un grupo o entidad que no sea un Estado ${ }^{119}$. Las

este respecto que en uno de los primeros proyectos presentados por los Estados Unidos para el artículo 51 figuraba expresamente que el derecho de legítima defensa podría ejercerse en caso de un ataque armado por parte de un Estado. Esta frase de «por parte de un Estado» se suprimió en la versión final, sin que esto diera lugar a un importante debate. Para más detalles sobre esta cuestión, cfr. VAN STEENBERGHE, R., «Self-Defence in Response to Attacks by Non-state Actors...», op. cit., p. 198.

117 Sobre esta doctrina, cfr. infra.

118 Cfr. Recueil, 2004, párrafo 139.

119 Cfr. Recueil, 2004, pp. 215, 230 y 242 respectivamente. 
tesis de la Corte han sido puestas en los últimos tiempos en duda no sólo porque son ilógicas, al no corresponderse estrictamente con el artículo 51, sino porque la propia evolución de la realidad internacional así lo impone.

Sin embargo, un año después la propia CIJ deja la cuestión en el aire al no pronunciarse sobre este aspecto en el Asunto de las actividades armadas sobre el territorio del Congo, indicando que no tenía necesidad de «... se prononcer sur les arguments des Parties relatifs à la question de savoir si et à quelles conditions le droit international contemporain prévoit un droit de légitime défense pour riposter à des ataques d'envergure menées par des forces irrégulières» ${ }^{120}$. No fue esta sin embargo la tesis que sostuvo el juez Kooijmans a las que se unió el juez Simma, quien en su Opinión individual sostuvo que siempre que se den las condiciones materiales para la legítima defensa, el Estado podrá recurrir a ella frente a un grupo armado irregular ${ }^{121}$. Esta tesis del juez Kooijmans es la que, tras los atentados del 11-S, ha recibido un amplio apoyo por parte de la doctrina y la práctica estatal. Por parte de la doctrina, autores como Pierre Michel Eisemann, Jost Delbrück, Karl Zemaneck, Christian Tomuschat, Luigi Condorelli, entre otros muchos, no han dudado en reconocer este derecho por varias razones jurídicas y lógicas ${ }^{122}$. Estos autores invocan en general la obligación que tienen los Estados de controlar efectivamente su territorio para impedir acciones terroristas. Esto mismo fue lo que se reprochó también al Líbano durante la guerra de Israel con Hezbolláh en el verano de 2006, denominada también la segunda guerra del Líbano, aunque en este caso, los requisitos exigidos por la Resolución 3314, tal y como han sido analizados por la CIJ, es evidente que no se reunían. Pero incluso sin que estemos ante una situación en que un grupo armado actúe desde un territorio, que sea formalmente hablando soberanía de un Estado, debe existir ese derecho de legítima defensa. Y esto es lo que ha ocurrido durante las dos últimas operaciones israelíes contra Hamás y otros grupos que atacaban a Israel indiscriminadamente desde la Banda de Gaza. Se trata de las Operaciones Plomo Fundido de 2009 y la de Margen Protector del verano de 2014 (la segunda ha sido la guerra más larga que ha llevado a cabo Israel -50

120 Cfr. Recueil, 2005, párrafo 147.

121 Ibid los párrafos 27 a 29 de la Opinión individual del juez Kooijmans y los párrafos 8 y 12 de la de Simma.

122 A este respecto, ver las tesis de estos autores en BERMEjO GARCÍA, R., «¿Puede la legítima defensa ponerse en un sitio? Algunos comentarios y reflexiones», en Estudios de Derecho Internacional y Derecho Europeo en homenaje al Profesor Manuel Pérez González, Tirant lo Blanch, 2012, pp. 208 y ss. 
días-), sin que se pueda considerar que Hamás sea un Estado en Gaza, aunque se comporte como tal. Desde esta perspectiva, la práctica estatal confirma un reconocimiento casi generalizado a Israel de poder recurrir a la legítima defensa, respetando, por supuesto, las condiciones para su ejercicio de la misma manera que para los Estados. Y esto es lo que se está haciendo ahora con el famoso EI que está siendo derrotado.

Pero la doctrina que se opone a las nuevas tendencias, y que ha analizado las acciones de estos grupos armados no estatales, siguen defendiendo las tesis clásicas como las más idóneas, considerándolas además como de lege lata. El Profesor Frank Latty, por ejemplo, es uno de ellos, y niega categóricamente que las acciones armadas francesas al amparo de la legítima defensa en Siria contra el EI sean legales. Es más, dice, siguiendo la jurisprudencia de la Corte Internacional de Justicia, que las acciones militares francesas constituyen una clara violación del artículo 2.4 de la Carta ${ }^{123}$. Esta opinión contrasta con las declaraciones que hicieron tanto el Presidente de la República, François Hollande ${ }^{124}$ como el Embajador de Francia ante la ONU, François Delattre ${ }^{125}$ y que son recogidas por el autor ${ }^{126}$.

${ }^{123}$ La opinión de este Profesor es clara y categórica, al indicar lo siguiente: «... face à Daech la France ne pourrait exercer sa légitime défense, collective (avant le 13 novembre) ou individuelle (depuis les attentats), sur le territoire syrien que dans deux cas de figure, qui s'avèrent tous deux inopérants: 1) si les comportements de Daech étaient attribuables à la Syrie-mais tel n'est factuellement pas le cas; 2) si Daech constituait un Etat, ayant supplanté la Syrie sur les portions de territoire qu'il contrôle. Son autoproclamation en tant qu'Etat islamique prenant la forme d'un califat, le contrôle indéniable qu'il exerce sur de vastes étendues territoriales, l'administration et même la monnaie qu'il s'efforce de mettre en place, bref les éléments d'effectivité étatique qui ressortent de la pratique ne doivent néanmoins pas occulter le fait que Daech demeure aux yeux de la communauté internationale (dont la France) un mouvement terroriste dont l'assise territoriale n'a pas fait disparaître les frontières internationalement reconnues qui séparent les deux Etats souverains que sont l'Irak et la Syrie... Si l'on s'en tient done à la jurisprudence de la CIJ, la France ne saurait invoquer la légitime défense pour bombarder Daech en Syrie; ses actions militaires seraient au contraire de nature à constituer une violation de l'interdiction fondamentale du recours à la force dans les relations internationales exprimée à l'article 2 et 4 , de la Charte des Nations Unies». Del autor, cfr. «La brouillage des repères du jus contra bellum. A propos de l'usage de la force par la France contre Daech», Revue générale de droit international public, 2016, p. 22.

124 «Cet ennemi nous le vaincrons ensemble, avec nos forces, celles de la République, avec nos armes, celles de la démocratie, avec nos institutions, avec le droit».

125 «Les attentats du 13 novembre ont constitué [...] une agression armé contre la France. Nos actions militaires dont nous avons informé le Conseil de sécurité dès l'origine, qui étaient justifiées par la légitime défense collective, peuvent désormais se fonder également sur la légitime défense individuelle conformément à l'article 51 de la Charte des Nations Unies».

${ }^{126} \mathrm{Ibid}, \mathrm{p} .10$. 
Mucho más acorde con la realidad existente sobre el terreno es el posicionamiento que ha adoptado el Director de Asuntos Jurídicos del Ministerio de Asuntos Exteriores francés, François Alabrune, para quien los ataques del EI perpetrados contra Irak son, por su gravedad, equivalentes a una agresión armada en el sentido del artículo 51, recordando a este respecto la Opinión de la Corte Internacional de Justicia sobre la licitud de la amenaza o del empleo de armas nucleares, en donde se recoge el derecho de un Estado de recurrir a la legítima defensa cuando su supervivencia esté en peligro ${ }^{127}$. Por otra parte, deja bien claro que el EI constituye una organización terrorista que controla un amplio territorio a caballo entre el Irak y Siria y que dispone de medios comparables a los de un Estado. Es más, señala que esta opinión es ampliamente compartida por los Estados, citando a Rusia como ejemplo ${ }^{128}$. Queda claro pues que François Alabrune defiende las nuevas tendencias.

Otro autor que, centrándose en el caso del EI, rechaza claramente las nuevas tendencias es Olivier Corten, quien critica acerbamente el comportamiento de algunos Estados en su lucha contra el terrorismo internacional. Para este autor, las nuevas tendencias en esta materia están lejos de reflejar la opinio juris de los Estados, siendo sobre todo apoyadas por los Estados Unidos y por algunos Estados de la Unión Europea ${ }^{129}$. Para este autor, la conclusión que se saca de la lucha contra el EI es la de una gran versatilidad, más preocupados por un cierto pragmatismo político que por la finura jurídica, al señalar lo siguiente:

«L'impression qui domine est done plutôt celle de la versatilité, dans un contexte davantage marqué par le pragmatisme politique que par la finesse de l'argumentation juridique. Tout le problème de cette crise -et ceci constitue sans doute toute son originalité- n'est pas de déterminer quelle serait

127 Sobre esta Opinión, cfr. Recueil, 1996, p. 263, párrafo 63.

128 A este respecto, cfr. ALABRUNE, F., «Fondements juridiques de l'intervention militaire française contre Daech en Irak et en Syrie», Revue générale de droit international public, 2016, pp. 40-50.

129 A este respecto, el Profesor Corten apunta lo siguiente: «Au vu de ces éléments, et spécialement des prises de position spécifiquement juridiques susceptibles de refléter l'opinio juris des États, il semblerait quelque peu excessif de considérer que les interprétations novatrices de la légitime défense, qu'elles soient déclinées 'à l'européenne' comme des mesures exceptionnellement dirigées contre un groupe terroriste sans viser l'État territorial, ou 'à la manière des Etats-Unis' comme conséquence du manque de volonté ou de capacité de cet État, auraient été acceptées par la communauté internationale des États dans son ensemble». Cfr. CORTEN, O., «L'argumentation des Etats européens pour justifier une intervention militaire contre 'l'Etat Islamique', en Syrie: vers une reconfiguration de la notion de légitime défense», Revue belge de droit international, 2016, p. 66. Se trata de un estudio bien documentado, aunque con la laguna de que no hay referencias a la doctrina hispana, que sigue a rajatabla los razonamientos tradicionales de la agresión indirecta. 
la base juridique adéquate pour justifier une intervention militaire. À partir du moment où il s'agit de frapper les forces rebelles qui s'opposent au gouvernement irakien comme syrien, la coopération et le consentement de ces deux États apparaissent juridiquement comme des bases solides et incontestables. Les membres de la coalition dirigée par les États-Unis ont cependant voulu éviter à tout prix de se fonder sur l'invitation du gouvernement Assad, et ce, pour des raisons dictées non par une quelconque conviction juridique mais des considérations d'opportunité politique» ${ }^{130}$

Algo de razón tiene el Profesor de Bruselas en el caso sirio, pero que no es bastante para rechazar sin más las nuevas tendencias en materia de legítima defensa.

Un estudio sumamente interesante sobre la legítima defensa contra los grupos no estatales es el de Nicholas Tsagourias, quien de una forma muy equilibrada y objetiva examina los problemas que plantean estos grupos armados a la hora de examinar nociones como el control del territorio, el hecho de saber si el Estado en donde llevan a cabo las actividades estos grupos es incapaz de actuar o si la falta de voluntad de hacerlo (unable or unwilling), así como la participación sustantiva son analizados con rigor, así como la debida diligencia $\mathrm{o}$, incluso la complicidad ${ }^{131}$. Muy interesante nos parece la aproximación que hace el autor entre el ataque llevado a cabo por un Estado o por un grupo no estatal equiparándolos en gran medida, aunque distinguiendo la aplicación de la legítima defensa como regla primaria cuando el Estado ha colaborado de forma sustancial en el ataque del grupo no estatal, y como regla secundaria, es decir responsabilidad internacional, cuando el ataque no se pueda atribuir al Estado, y el grupo armado haya llevado el ataque motu propio ${ }^{132}$.

\footnotetext{
${ }^{130} \mathrm{Ibid}$, p. 67.

131 TSAgOURIAS, N., «Self-Defence against Non-State Actors...», op. cit., pp. 807 y ss.

132 «In summary, what constitutes state authorship of an armed attack is quite broad and includes actual as well as constructive authorship under the label of substantial involvement. In all these cases, the victim state can use force by way of self-defence against the perpetrator state. If, however, the assistance provided to non-state actors does not amount to substantial involvement, the assisting state does not become the author of the armed attack but it may be held responsible for violating assorted international law obligations arising from treaties, customary law, Security Council resolutions or from the duty of due diligence.

Is a non-state actor commits an armed attack independently from states or when there is insubstantial state involvement, the non-state actor becomes the author of the attack and consequently the target of self-defence, according to self-defence as a primary rule. In this case, because the self-defence action is carried out on the territory of a state that is not the author of the armed attack, it violates obligations owned to that state. It is at this juncture that self-defence as a secondary rule becomes operative». Ibid, p. 819 .
} 
Pero también ha habido autores, no muy citados por la doctrina, que ya antes de que se produjeran los ataques y la ocupación de territorios del EI en Irak y Siria se pronunciaron sin tapujos sobre el tema de los actores no estatales y si sus ataques podrían dar lugar a la legítima defensa. En efecto, Jörg Kammerhofer ${ }^{133}$, es uno de ellos e insiste en el hecho de que el artículo 51 de la Carta recoge solo la expresión de «en caso de ataque armado», sin especificar que el ataque deba producirse directamente por un Estado, algo que ya se ha apuntado. Por lo tanto, el ataque puede producirse por grupos armados no estatales, y a este respecto menciona las Opiniones individuales de Kooijmans y Simma, ya citadas, que siguen las tesis defendidas también por Yoran Dinstein ${ }^{134}$. Después pasa revista a las tesis que intentan establecer algún vínculo con el Estado de donde procede el ataque (tolerancia, aquiescencia, o el apoyo a estos grupos armados), en donde recoge expresamente la frase de la Corte Internacional de Justicia en el asunto del Congo en donde se señala que «las partes admiten que, en principio, el apoyo prestado a fuerzas irregulares puede, en ciertas circunstancias, equivaler a un ataque armado». Así las cosas, el autor hace el razonamiento siguiente en relación con la legítima defensa en estos casos, según el cual la respuesta a los ataques de estos actores no estatales al amparo de la legítima defensa no están prohibidos, al no incurrir el Estado que la invoca en responsabilidad internacional ${ }^{135}$. Y el autor termina su estudio bastante insatisfecho, sobre todo con la jurisprudencia de la Corte Internacional de Justicia, en donde hay, dice, una clara minoría que critica sus posicionamientos, sin que esto quiera decir que los que deciden guardar silencio, haya que interpretarse que compartan completamente las tesis de la Corte ${ }^{136}$.

Todos estos autores reconocen, pues, que algo está cambiando, incluso aquellos que no quieren reconocer las denominadas nuevas tendencias que se están desatando sobre todo a la luz de una práctica cada vez más extendida por parte de los Estados, incluida Rusia. Tanto es así que si se examina la práctica de los Estados antes de que se lanzara la Operación Libertad Duradera tras al $11-\mathrm{S}$, y esa misma práctica después, es evidente que el cambio ha sido muy im-

\footnotetext{
133 De este autor, cfr. «The Armed Activities Case and Non-state Actors in Self-Defence Law», Leiden Fournal of International Law, 2007, pp. 89-113.

${ }^{134} \mathrm{Ibid}$, p. 99 y ss.

135 «On the face of it, the answer seems clear: armed attacks are not illegal, because article 51 does not prohibit them - a state does not incur state responsibility for armed attacks themselves, even though the same actions may very well violate the prohibitions of the use of force or aggression». Ibid, p. 107.

${ }^{136} \mathrm{Ibid}$, p. 112.
} 
portante, como señala Raphaël van Steenberghe, quien hace hincapié en que muchos casos de la práctica internacional revelan que no es necesario que el Estado que recurra a la legítima defensa no necesita probar una participación substantiva del Estado en caso de ataques provenientes de grupos armados no estatales desde su territorio ${ }^{137}$. Además, la práctica reciente también nos proporciona elementos referentes a la gravedad que el ataque deba alcanzar para poder invocar la legítima defensa, así como la proporcionalidad que esta debe tener.

Como es sabido fue la Corte Internacional de Justicia, en el asunto de Nicaragua la bombera pirómana al indicar que un ataque armado leve no podía dar lugar a contramedidas colectivas que implicaran el uso de la fuerza. Dicho de otra forma, un ataque de esta índole no podía dar lugar a la legítima defensa, y que el Estado que lo llevara a cabo asumiría, eso sí, la responsabilidad internacional. Evidentemente, esta cuestión plantea el problema de saber si existe o no un umbral a partir del cual se podría invocar la legítima defensa o no. El tema es en sí bastante escurridizo, porque habría que distinguir entre un caso aislado de un uso leve de la fuerza en determinadas circunstancias, de aquellos que, siendo leves, son tan repetitivos que dejan de serlo. Y es que un Estado tiene el derecho a vivir en paz y seguridad, y a no ser hostigado por otros Estados, o por entidades que actúan desde el territorio de estos. Desde esta perspectiva, es ridículo pensar que si un Estado es objeto de ataques, aunque estos sean leves, a su soberanía territorial, este no pueda actuar siempre y cuando se respeten las reglas aplicables a la legítima defensa. El problema se

$137 \ll$ The correct interpretation of recent state practice amounts to considering that the latter evidences a clear tendency towards allowing states to act in self-defence in response to attacks, even if these attacks are coomitted only by non-state actors. Such a tendency had already emerged in 2001 from the wide support given to Operation Enduring Freedom. As a result, one should conclude more precisely, if one does not analyse the recent state practice separately -that is, without taking into account Enduring Freedom- that this practice actually conforms the evolution of the law of self-defence. In other words, in view of recent state practice, which supplements Enduring Freedom, private armed attacks nowadays seem to be enough to trigger the right of self-defence of the victim state...

This conclusion does not mean that no link has to be established between the state acting in self-defence and the state in whose territory the action takes place. Such a link, clearly evidenced by recent state practice, is in fact required by the condition of necessity of the law of self-defence. It serves to demonstrate that the harbouring state is at least unable or unwilling to prevent attacks from being committed from its territory so that its police forces cannot be considered by the victim state an available means of protecting itself and that resorting to self-defence therefore becomes necessary». De este autor, cfr. «Self-Defence in Response to Attacks by Non-state Actors in the Light of Recent State Practice: A step Forward?», op. cit., p. 207. 
puede plantear cuando el Estado atacado lanza otros en lugares distintos que no tengan ninguna relación con el ataque inicial, pues se caería en las represalias. Este posicionamiento de la Corte en el asunto de Nicaragua sería, a pesar de su ambigüedad, un puente de referencia para que la doctrina restriccionista se negara a reconocer la legítima defensa en muchos casos. No obstante, si se toman en consideración todos estos aspectos, las tesis restrictivas parecen bastante exageradas y contraproducentes, si es que se trata de defender el mantenimiento de la paz y de la seguridad internacionales ${ }^{138}$.

El tema se ha ido al fin y al cabo aclarando un poco a pesar del lío que montó la Corte al no poner ejemplos de ataques que podrían ser considerados como leves y cuáles no. Y es que, evidentemente, habría que ir caso por caso y tomar en consideración todas las circunstancias pertinentes para ver realmente cuando estaríamos en una u otra situación. Pero lo cierto es que la Corte ha vuelto sobre el asunto para introducir un poco de claridad en el túnel que construyó en el asunto de Nicaragua, y lo ha hecho parcialmente en el asunto de las Plataformas petrolíferas, al indicar que el umbral del uso de la fuerza que da lugar a la legítima defensa puede ser $\ll . .$. le minage d'un seul navire de guerre» ${ }^{139}$. Sin embargo, quien ha dejado más clara esta cuestión ha sido la Misión Independiente de Investigación sobre el conflicto en Georgia en donde se indica que la «prohibition of the use of forcé covers all physical forcé which surpasses a mínimum threshold of intensity... [o]nly very small incidents lie below this threshold, for instance the targeted killing of single individuals, forcible abductions of individual persons, or the interception of a single aircraft ${ }^{140}$.

Desde esta perspectiva, nos parece evidente que repetidos ataques menores o leves pueden ser interpretados en virtud de su acumulación como un ataque armado, algo que el que subscribe estas líneas ya defendió en $1993^{141}$.

\footnotetext{
${ }^{138}$ Para un análisis de las respectivas tesis véase DE HoOG, A., «Restrictivist Reasoning on the Ratione Personae Dimension of Armed Attacks in the Post 9/11 World», Leiden Fournal of International Law, 2016, pp. 19-42.

139 Cfr. Recueil, 2003, pp. 195-196.

140 Cfr. INDEPENDENT INTERNATIONAL FACT-FINDING MisSION ON THE CONFLiCT IN GEORGIA, REPORTS 242 \& n. 49, September 2009, en http://www.ceiig.ch/report.html. Para un estudio muy exhaustive sobre esta cuestión y su evolución, cfr. RUYS, T., «The meaning of 'Force' adn the Boundaries of the Fus ad Bellum: ave 'Minimal' Uses of Force Excluded from UN Charter Article 2 (4)?», AfIL, 2014, $\mathrm{n}^{\circ}$ 2, pp. 159-210. Como se puede comprender el enunciado del título de este estudio ya nos dice qué derroteros adopta el autor, con amplias referencias doctrinales.

${ }^{141}$ Cfr. Bermejo García, R., El marco jurídico internacional en materia de uso de la fuerza..., op. cit., pp. 290 y ss., así como en otros trabajos posteriores.
} 
$\mathrm{Y}$ es que no se puede obligar a un Estado a permanecer pasivo frente a repetidos ataques de estos grupos no estatales por mucho que estos sean leves. La práctica que a este respecto ha mantenido Israel ha sido ejemplar, práctica que después se ha ido extendiendo a otros Estados, como por ejemplo recientemente Turquía. Así las cosas, compartimos plenamente la opinión de Raphaël Van Steenberghe, que indica lo siguiente:

«To sum up, recent state practice greatly contributes to the evolution of the law of self-defence, mainly to the extent that, analysed altogether with Operation Enduring Freedom, it implies the recognition of the right to respond in self-defence to private armed attacks, but also because it gives weight to some controversial interpretations of the classical conditions of this law, such as that according to which the gravity of the attacks must be assessed by aggregating a succession of minor -but linked- acts of force, or such as that according to which the condition of proportionality implies a quantitative assessment of the action taken in self-defence, but only as a means of making an easy prima facie judgement on the necessity of this

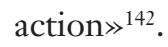

\section{La lucha contra el EI y el Consejo de Seguridad DE LAS NACIONES UNIDAS}

La complejidad que encierra un grupo armado como el EI, en una zona donde hay conflictos internos que suscitan diversos intereses directos e indirectos a las potencias mundiales y regionales, traería consigo una serie de dificultades a la hora de tratar el tema de la lucha contra el EI en el seno del Consejo de Seguridad. Además, hay que recalcar que, sobre todo, en Siria el antagonismo

${ }^{142}$ Cfr. «The Self-Defence in Response to Attacks by Non-State Actos in the Light of Recent State Practice: A Step Forward?», op. cit., p. 207. Categórica es también a este respect Karin OellersFrahm, cuando dice que: «... In case of an armed attack by a state or a non-State actor the victim state is empowered under art. $51 \mathrm{UN}$ Charter to take the same measures as the SC would be competent to take under Chapter VII, art. 39, 41 and 42 UN Charter. As the SC has already explicitly stated (in particular Res. 1368 [2001] and 1373 [2001] that also attacks of non-State actors, not only those of states, may endanger international peace and security the measures provided for in Chapter VII including the right to self-defence may be taken also in case of an armed attack by a non-State actor». De esta autora, cfr. «Article 51-What Matters Is the Armed Attack, not the Attaques», en Peters, A. y MarXsen, Ch. (eds.), Self-Defence against Non-State Actors: Impulses from the Max Planck Trialongues on the Law of Peace and War, op. cit., p. 46. 
que se había desatado entre los países occidentales, con los Estados Unidos a la cabeza, y la Federación Rusa ha estado siempre a flor de piel desde los inicios del conflicto en Siria, por lo que no resultaba fácil articular unos objetivos comunes en la lucha contra los grupos rebeldes opositores al régimen sirio, primero, ni contra el EI después, y eso que entre los grupos opositores al régimen de Al-Assad, algunos de ellos han destacado por sus ataques terroristas. Con estas premisas era obvio que la lucha contra el EI, a pesar de todas estas dificultades, terminaría siendo objeto de estudio en el Consejo de Seguridad, aunque las medidas que este órgano onusiano ha adoptado, no fueron lo contundentes que muchos esperaban. $\mathrm{Y}$ es que, se quiera o no reconocer, el Consejo de Seguridad, a pesar de las amplias competencias que tiene en materia de adopción de decisiones previsto en el artículo 27.3 de la Carta, sigue siendo un obstáculo importante, debido, como se sabe, al famoso derecho de veto de cada uno de los cinco Miembros permanentes. No obstante, el Consejo de Seguridad ha «autorizado» en casos que son ya muy conocidos el uso de la fuerza desde la famosa Resolución 678 del 2 de noviembre de 1990 tras la invasión de Kuwait por Irak, al amparo de la expresión de «todas las medidas necesarias».

Sin embargo, el Consejo de Seguridad, dadas las dificultades presentes en la zona a las que hemos hecho alusión anteriormente, ha tardado en ocuparse expresamente del EI, empezando su andadura con la Resolución 2170 del 15 de agosto de 2014, en donde se reconoce el efecto desestabilizador que representa tanto el EI como el Frente Al-Nusra no solo sobre Siria e Irak, sino sobre toda la región, señalando al mismo tiempo que representan una amenaza a la paz y a la seguridad internacionales. Bajo estas premisas, el Consejo continuaría por estas sendas dando un paso adelante, al situarse ya en el seno del Capítulo VII de la Carta, al adoptar por unanimidad la Resolución 2178, del 24 de septiembre de 2014, en la que se adoptan determinadas medidas de lucha contra el terrorismo, incidiendo en el párrafo 5 sobre la urgente necesidad de aplicar la Resolución a los combatientes terroristas extranjeros asociados con el EI, el grupo Al-Nusra y otras células, entidades o grupos derivados de Al-Qaida. Y es que como se sabe, el EI se ha nutrido de una manera importante de combatientes procedentes de otros países europeos y de la Federación Rusa ${ }^{143}$, los cuales son autores de ejecuciones sumarias execrables y

\footnotetext{
${ }^{143}$ Sobre Rusia y el Yiadismo, cfr. Pardo de Santallana y Gómez de Olea, J., «Federación Rusa y yiadismo radical», Instituto Español de Estudios Estratégicos, Documento Análisis 56/2017, de 27 de septiembre de 2017, 15 p.
} 
atentados terroristas en sus países de origen, tras ser entrenados por el propio EI, así como otras graves violaciones del Derecho internacional humanitario. Por lo tanto, esta Resolución se sitúa en el marco general de lucha contra el terrorismo internacional que se inició con la famosa Resolución 1373 de 28 de septiembre de 2001, tras el 11-S.

Cabe preguntarse, no obstante, por qué el Consejo de Seguridad no adoptó una resolución que recogiera expresamente la autorización del uso de la fuerza. Las razones se pueden deducir fácilmente a causa de la situación política existente en la zona, y con una Rusia vetando los proyectos de resolución presentados por los países occidentales que representaban ciertos riesgos para el régimen de $\mathrm{Al}-\mathrm{Assad}$, mientras que estos últimos hacían lo propio con cualquier iniciativa rusa. $\mathrm{Y}$ es que Rusia ha aplicado a rajatabla la famosa frase de que en Siria no se haría lo que se hizo en Libia, y así ha sido. Es más, el escepticismo occidental frente a la Federación Rusa ha ido hasta el extremo de oponerse a una resolución propuesta por Rusia en la que se quería asociar a Siria en la lucha contra el $\mathrm{EI}^{144}$. Pero las cosas iban a cambiar un poco a raíz de la explosión en pleno vuelo del avión de la compañía rusa Metrojet en el Sinaí el 31 de octubre de 2015 y, un poco más tarde, los atentados del 13 de noviembre del mismo año en Francia que, como sabemos, y ya hemos apuntado, dieron lugar a la invocación por este país de la cláusula de defensa mutua del artículo 42.7 del TUE. Así las cosas, se podría esperar de buena fe que el Consejo de Seguridad pudiera adoptar un mandato claro que autorizara el uso de la fuerza contra el EI. Sin embargo, nada de esto iba a ocurrir tras la adopción de la Resolución 2249 del 20 de noviembre de 2015.

En efecto, a pesar de que el texto de la Resolución fue elaborado por Francia, país que siete días antes había sido objeto de los graves atentados terroristas reivindicados por el EI, que causaron 130 muertos y unos 600 heridos, Rusia se opuso desde el primer momento a que para el caso sirio se siguiera el mal ejemplo que había representado la Resolución 1973 de 2011 en el caso libio, que terminó derrocando y asesinando al líder libio Gadafi. Y es que para Rusia, si con la Resolución 1973 se derrocó a Gadafi, pensaba que con una resolución en la que se autorizara el uso de la fuerza, el régimen de Al-Assad podía correr la misma suerte, de ahí su rechazo al proyecto francés desde el primer momento, aunque fuera de forma constructiva. Tanto es así que el 13 de noviembre,

\footnotetext{
${ }^{144}$ A este respecto, cfr. «A l'ONU, scepticisme des diplomates occidentaux face aux intentions russes en Syrie», Le Monde, de 30 de septiembre de 2015.
} 
día de los atentados en Francia, Rusia propone una nueva versión del proyecto presentado ya el 30 de septiembre, aunque también sin éxito. No obstante, el proyecto francés sería avalado por Rusia una vez que introdujo sus demandas como entre otras la mención a la Carta de las Naciones Unidas, en el párrafo 5 de la Resolución, así como la mención en el último párrafo del preámbulo al hecho de «que la situación seguirá deteriorándose mientras no exista una solución política del conflicto en Siria y poniendo de relieve la necesidad de que se aplique el Comunicado de Ginebra de 30 de junio de 2012..., el comunicado conjunto sobre el resultado de las conversaciones multilaterales relativas a Siria..., y la declaración del Grupo Internacional de apoyo a Siria, de 14 de noviembre de 2015». Es decir, las pretensiones rusas están presentes en la Resolución, e introducen aspectos de multilateralidad en la que ella obviamente está presente. Así las cosas, y en este ambiente constructivo, no es extraño que el Representante ruso en el Consejo de Seguridad, Churkin, afirmara que naturalmente, no podíamos sino apoyar un proyecto de resolución presentado por Francia, ya que a pesar de que se preparó en circunstancias especiales y con un tiempo muy ajustado, sí que se incorporaron las importantes enmiendas de Rusia $^{145}$, entre otras cosas en lo que se refiere a la utilización de la fuerza. A este respecto, el Sr. Churkin reconoce que «era importante que ese aspecto quedara reflejado en el texto y de hecho, así ha sido».

Dicho esto lo cierto es que a pesar de que la Resolución 2249 haya sido adoptada por unanimidad, sin embargo reina en ella una gran ambigüedad, sobre todo en materia de uso de la fuerza. Una buena prueba de ello es el párrafo 5 de la Resolución, que reza así:

«Exhorta a los Estados Miembros que tengan capacidad para hacerlo a que adopten todas las medidas necesarias, de conformidad con el derecho internacional, en particular la Carta de las Naciones Unidas y el derecho internacional de los derechos humanos, el derecho internacional de los refugiados y el derecho internacional humanitario, sobre el territorio que se encuentra bajo el control del EIIL, también conocido como Daesh, en Siria y el Iraq, redoblen y coordinen sus esfuerzos para prevenir y reprimir los actos terroristas cometidos específicamente por el EIIL, también conocido como Daesh, así como el Frente Al-Nusra, y todas las demás personas, gru-

145 Cfr. Doc. S/PV.7565, p. 5. Para más detalles sobre estas cuestiones, cfr. GuTIÉrREZ EsPADA, C., «Choque de civilizaciones (el autoproclamado estado islámico)...», op. cit., pp. 178-179; y LATTY, F., «Le brouillage des repères du jus contra bellum...», op. cit., pp. 31 y ss. 
pos, empresas y entidades asociados con Al-Qaida y otros grupos terroristas designados por el Consejo de Seguridad de las Naciones Unidas, y los que acuerde el Grupo Internacional de Apoyo a Siria y corrobore el Consejo de Seguridad, de conformidad con la declaración del Grupo Internacional de Apoyo a Siria de 14 de noviembre, y erradiquen el cobijo que han establecido en partes importantes del Iraq y Siria».

De este párrafo cabe decir lo siguiente. Lo primero que salta a la vista es que el Consejo no «autoriza», las medidas necesarias ${ }^{146}$, o lo que es lo mismo el uso de la fuerza, sino que solo «exhorta» a los Estados miembros de la ONU a que adopten las medidas necesarias, aunque solo a aquellos que tengan capacidad para llevarlas a cabo ${ }^{147}$. Lo segundo es que esas medidas se tienen que llevar a cabo de conformidad con el Derecho internacional, en particular la Carta de las Naciones Unidas, etc. Se ve perfectamente pues la huella rusa, tal y como ya hemos apuntado. Lo tercero es que esas «medidas necesarias» solo se pueden llevar a cabo sobre el territorio que esté controlado por el EI, tanto en Irak como en Siria. Por último, y lo más importante, y que constituye otra debilidad de esta Resolución es que no lleva el sello del Capítulo VII de la Carta onusiana, cuando es lo que se ha hecho desde la Resolución 678. Desde esta perspectiva, no es extraño que en general los autores hayan reprochado a esta Resolución una ambigüedad digna de elogio, y que dadas las circunstancias presentes en la zona, se hubiera tenido que aclarar no solo el texto, sino también el contexto ${ }^{148}$.

Pero si la ambigüedad reina por doquier en esta Resolución, no conviene perder de vista lo siguiente. Es cierto que esta Resolución no menciona expresamente el derecho de legítima defensa, pero esto no quiere decir que los Estados no puedan invocarla, pues es un derecho de los Estados, hasta que

\footnotetext{
146 Como se sabe esta expresión es la misma que la que se utilizó por primera vez en la muy comentada Resolución 678 de 1990 en relación con la liberación de Kuwait que había sido ocupado por las tropas iraquíes de Sadam Hussein en 1990, expresión que se insertó precisamente a iniciativa rusa.

${ }^{147} \mathrm{El}$ texto francés de la Resolución utiliza el término «Demande», mientras que el inglés recurre a la excpresion «Calls upon», término este último que figuraba ya en el proyecto de resolución ruso del 30 de septiembre de 2015. Conviene apuntar que el texto de la Resolución fue redactado y adoptado en inglés, antes de traducirlo al francés y a los otros idiomas, y subsisten, sobre todo en francés ciertas imprecisiones que el Profesor Latty ha puesto bien de manifiesto. Cfr. LatTy, F., «Le brouillage des repères du jus contra bellum. A propos de l'usage de la force par la France contre Daesch», op. cit., pp. 32-33, nota 103.

148 Por ejemplo, cfr. AKande, D. y Milanovie, M., «The Constructive Ambiguity of Security Council's ISIS Resolution», en www.ejietalk.org, publicado el 21 de noviembre de 2015. Ver también los estudios de Frank Latty, Gutiérrez Espada y Pozo Serrano, ya citados.
} 
el Consejo adopte las medidas necesarias. Es más, la propia Resolución inicia su parte dispositiva condenando inequívocamente en su párrafo primero «los horrendos ataques terroristas» perpetrados por el EI y por el Daesh, por lo que el hecho de que no mencione la legítima defensa, esto no quiere decir que ya pone fin al derecho de legítima defensa de los Estados, que es un derecho inmanente. Para que esto fuera así sería necesario que las medidas adoptadas por el Consejo fueran «las necesarias» para mantener la paz y la seguridad internacionales, como reza el artículo $51^{149}$.

$\mathrm{Y}$ es que, en cuanto al carácter provisional de la legítima defensa, cabe resaltar que el problema que plantea la interpretación del artículo 51 es saber el momento a partir del cual el derecho del Estado a ejercer la legítima defensa deja de existir en beneficio de las competencias del Consejo de Seguridad y, a este respecto, la cuestión esencial consiste en dilucidar si el Consejo de Seguridad ha adoptado realmente «las medidas necesarias para mantener la paz y la seguridad internacionales». Cabe señalar que el texto habla de «medidas necesarias» y no de «medidas adecuadas» como sugirió la delegación estadounidense. Asimismo se habla de «mantener» la paz o «restablecerla, lo que no implica que se tenga que restablecer forzosamente el statu quo precedente al ataque armado, sino sólo de mantener la paz y la seguridad internacionales.

A nuestro entender, la adopción de medidas necesarias implica que el Consejo de Seguridad haya reaccionado con alguna acción positiva. Saber además si estas medidas son necesarias o no es una cuestión que debe ser analizada a la luz de todas las circunstancias de cada caso individual. De todas formas, el traspaso de las competencias del Estado en beneficio del Consejo solo tendrá lugar el día en que éste haya adoptado las medidas efectivas con el fin de hacer frente a la situación y sustituirse así en la acción del Estado atacado ${ }^{150}$. Así las cosas, es evidente que con esta Resolución, el Consejo no pretende paralizar la legítima defensa de los Estados que la han invocado, pues en nuestra opinión estos han actuado de conformidad con el Derecho internacional y con la Carta de las Naciones Unidas. Este era el sentir al menos del representante francés ante el Consejo de Seguridad tras la aprobación de la Resolución, al señalar claramente que los atentados del 13 de noviembre de 2015 (en Francia) constituyeron un acto de agresión armada contra su país, a pesar de que esa

149 Cfr. Pozo Serrano, P., «El uso de la fuerza contra el EI en Irak y Siria», op. cit., pp. 180 y ss.

${ }^{150}$ Conviene citar a este respecto la precisión que hizo en la Conferencia de San Francisco la delegación colombiana según la cual las medidas en legítima defensa durarían «hasta que el Consejo de Seguridad pueda adoptar las sanciones apropiadas contra el Estado agresor». 
agresión procedía de un actor no estatal ${ }^{151}$. El representantes francés se suma así a estas nuevas tendencias que cada vez con más fuerza aplican los Estados para defenderse de los ataques de estos grupos armados no estatales ${ }^{152}$.

\section{CONCLUSIÓN}

Es evidente que las nuevas tendencias que se han venido forjando en las últimas décadas en relación con el uso de la fuerza contra los actores no estatales se han confirmado en el caso del EI, como no podía ser de otra manera. Desde esta perspectiva, la práctica internacional en el caso del EI ha seguido la que se hizo con Hezbolláh en la denominada segunda guerra del Líbano del verano de 2006, y refleja claramente que los Estados recurren sin tapujos a la legítima defensa frente a los ataques de grupos armados no estatales, ataques que no son ni imputables a un Estado ni en los que hay una participación sustancial del Estado. Es decir, se admite el derecho de legítima contra un grupo armado no estatal cuando los Estados en cuyo territorio se encuentran dichos grupos no pueden o no quieren poner fin a sus ataques. Se constata además en esta materia una cierta descentralización del poder coercitivo internacional, ya que el Consejo de Seguridad se abstiene en general de adoptar medidas coercitivas, dejando a los Estados que actúen recurriendo a la legítima defensa o en virtud del consentimiento del Estado territorial respectivo. Esto no solo ha ocurrido en el caso del EI en Irak y Siria, sino también en Libia a la luz de la Resolución 2259, de 23 de diciembre de 2015. No obstante, conviene recalcar que esta realidad contrasta con los posicionamientos de la jurisprudencia de la Corte Internacional de Justicia que sigue en su mundo del siglo pasado o echando balones fuera, aunque el crucero en el que se cobijan los jueces haya ya recibido algunos misiles en su proa, que hacen que se tambalee...

${ }^{151}$ El representante de Francia ante el Consejo de Seguridad fue muy contundente al señalar lo siguiente: «Los atentados del 13 de noviembre constituyeron un acto de agresión armada contra Francia. Nuestras medidas militares, de las que hemos informado al Consejo de Seguridad desde el principio, que estaban justificadas como medidas de legítima defensa colectiva, pueden en adelante fundamentarse igualmente en la legítima defensa individual, de conformidad con el artículo 51 de la Carta de las Naciones Unidas. Sobre la base de esta resolución histórica del Consejo de Seguridad, Francia proseguirá y aumentará sus esfuerzos para movilizar a toda la comunidad internacional a fin de vencer a nuestro enemigo común». Cfr. Doc. S/PV7565, p. 2.

152 A este respecto, cfr. AlabrunE, F., «Fondements juridiques del'intervention militaire française contre Daech en Irak et en Syrie», op. cit., p. 47. 
